Review

\title{
A Critical Review on Recycling Composite Waste Using Pyrolysis for Sustainable Development
}

\author{
Ramez Abdallah ${ }^{1,2, *}$, Adel Juaidi ${ }^{1}{ }^{(}$, Mahmut A. Savaş $^{2}$, Hüseyin Çamur $^{2}{ }^{2}$, Aiman Albatayneh ${ }^{3} \mathbb{C}$, \\ Samer Abdala ${ }^{4}$ and Francisco Manzano-Agugliaro ${ }^{5, *}$ (i)
}

1 Mechanical \& Mechatronics Engineering Department, Faculty of Engineering \& Information Technology, An-Najah National University, P.O. Box 7, Nablus 00970, Palestine; adel@najah.edu

2 Department of Mechanical Engineering, Faculty of Engineering, Near East University, via Mersin 10, 99138 Nicosia, Turkey; mahmut.savas@neu.edu.tr (M.A.S.); huseyin.camur@neu.edu.tr (H.Ç.)

3 Energy Engineering Department, School of Natural Resources Engineering and Management, German Jordanian University, Amman 11180, Jordan; aiman.albatayneh@gju.edu.jo

4 Oilserv Company, 15th Floor, One by Omniyat Tower, Business Bay,

Dubai P.O. Box 117648, United Arab Emirates; Samer.Abdala@oilserv.com

5 Department of Engineering, CEIA3, University of Almeria, 04120 Almeria, Spain

* Correspondence: ramezkhaldi@najah.edu (R.A.); fmanzano@ual.es (F.M.-A.)

\section{check for} updates

Citation: Abdallah, R.; Juaidi, A.; Savaş, M.A.; Çamur, H.; Albatayneh, A.; Abdala, S.; Manzano-Agugliaro, F. A Critical Review on Recycling Composite Waste Using Pyrolysis for Sustainable Development. Energies 2021, 14, 5748. https://doi.org/ $10.3390 /$ en14185748

Academic Editor: Dimitrios

Katsaprakakis

Received: 27 August 2021 Accepted: 8 September 2021 Published: 13 September 2021 Retracted: 17 October 2022

Publisher's Note: MDPI stays neutral with regard to jurisdictional claims in published maps and institutional affiliations.

Copyright: (c) 2021 by the authors. Licensee MDPI, Basel, Switzerland. This article is an open access article distributed under the terms and conditions of the Creative Commons Attribution (CC BY) license (https:/ / creativecommons.org/licenses/by/ $4.0 /)$.

\begin{abstract}
The rising usage of carbon and glass fibers has raised awareness of scrap management options. Every year, tons of composite scrap containing precious carbon and glass fibers accumulate from numerous sectors. It is necessary to recycle them efficiently, without harming the environment. Pyrolysis seems to be a realistic and promising approach, not only for efficient recovery, but also for high-quality fiber production. In this paper, the essential characteristics of the pyrolysis process, their influence on fiber characteristics, and the use of recovered fibers in the creation of a new composite are highlighted. Pyrolysis, like any other recycling process, has several drawbacks, the most problematic of which is the probability of char development on the resultant fiber surface. Due to the char, the mechanical characteristics of the recovered fibers may decrease substantially. Chemically treating and post-heating the fibers both help to reduce char formation, but only to a limited degree. Thus, it was important to identify the material cost reductions that may be achieved using recovered carbon fibers as structural reinforcement, as well as the manufacture of high-value products using recycled carbon fibers on a large scale. Recycled fibers are cheaper than virgin fibers, but they inherently vary from them as well. This has hampered the entry of recycled fiber into the virgin fiber industry. Based on cost and performance, the task of the current study was to modify the material in such a way that virgin fiber was replaced with recycled fiber. In order to successfully modify the recycling process, a regulated optimum temperature and residence duration in post-pyrolysis were advantageous.
\end{abstract}

Keywords: recycling; reinforced composites; pyrolysis; CFRC; GFRC; carbon fiber; glass fiber; sustainability

\section{Introduction}

Composite materials are composed of two or more different materials having considerably different physical and/or chemical characteristics that, when merged, produce a material with attributes that differ from the separate elements. Composite materials are extensively utilized in the automobile, construction, transportation, aerospace, and renewable energy applications due to their durability, high strength, great quality, minimal maintenance, and low weight [1-3].

In recent years, a few significant occurrences occurred that significantly increased the sociotechnical push for long-term composite recycling, particularly:

1. The increased utilization of composites in mass-production automobiles resulting from the development of high-volume thermoplastic composite-based technologies [3]. 
2. The first significant group of wind turbines made of composite materials approaching their End-of-Life (EOL) in 2019-2020 and preparing to be dismantled [1].

3. A global prohibition on composite landfilling in several countries [1,4].

4. The COVID-19 epidemic hastening the retirement of airplanes (airplane mass decommissioning is predicted in the 2020s) [5].

According to Stella Job, the absence of recycling facilities is an obstacle to the expanded usage of glass fiber reinforced composite (GFRC) and carbon fiber-reinforced composite (CFRC) composites [6]. Therefore, the growing usage of these significant materials-along with landfilling limits and prohibitions-necessitated the development of viable composite recycling methods [7]. As the EU moves closer to eliminating landfill alternatives, it is reasonable to predict that such sociotechnical stress will surely increase in the near future [4], It is also worth noting the ever-increasing number of wind turbines that have reached the end of their useful life and are ready to be burned or recycled, as well as the expansion of composite markets and increased composite manufacturing and installation rates (As presented in Figure 1). Additionally, decommissioning will continue to increase the number of installed wind turbines, year after year, as it has in the past [4]. As a result, the motivation to create the most sustainable composite recycling technologies is undoubtedly critical to the composite industry's preservation and success. It has been predicted that this trend will become increasingly significant in the 2020s.

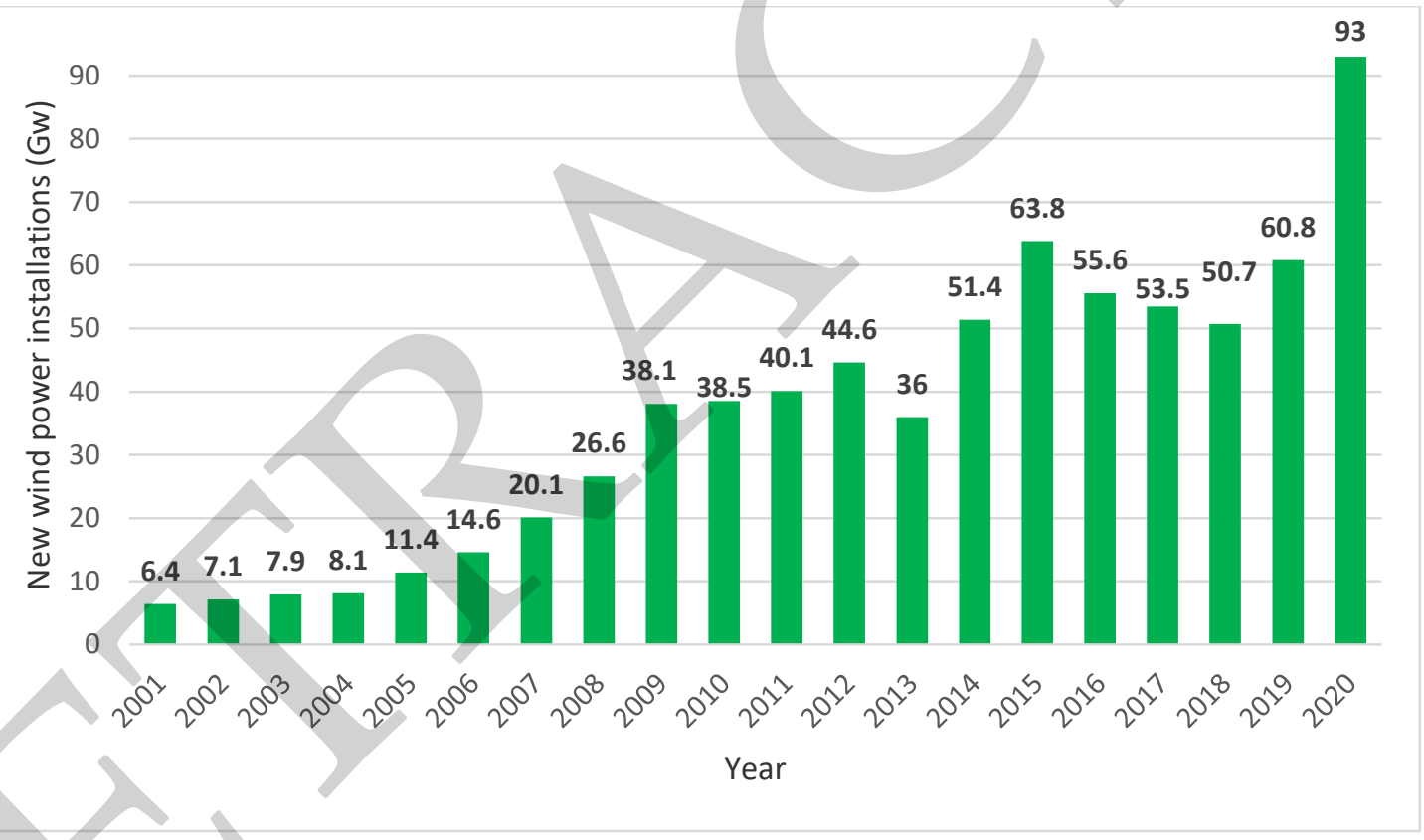

Figure 1. Added wind capacity in the globe each year for 2001-2020 [8].

The use of composites is most prevalent in the wind energy, marine, aerospace, and automotive industries. In these cases, recent advancements have led to a greater emphasis on material EOL management [9].

\subsection{Composite Material Applications}

\subsubsection{Aerospace}

Over the next ten years, the International Air Transport Association (IATA) estimates that 11,000 aircraft will be retired [5]. The COVID-19 pandemic has severely curtailed aviation travel, and this is likely to hasten the decommissioning of these planes, emphasizing the importance of recycling. Moreover, composite utilization in airplanes has increased dramatically, as is clear in the commercial aircraft produced by Airbus and Boeing. Take, for example, the usage of composites in the Airbus commercial aircraft A300 (4.5 wt $\%$, 
1971-2007) and B787 (50 wt\%, 2007-present) [10]. By weight, the B787 body is 50\% composites, $10 \%$ steel, $15 \%$ titanium, $20 \%$ aluminum (Al), and 5\% other. Meanwhile, the composite material in B787 consists mainly of carbon sandwich structures, CFRP laminates, and fiberglass [1]. In the aircraft sector, $\mathrm{Al}$ has long been one of the most utilized materials. However, its utilization rate has dropped from $50 \%$ in the Boeing B777 to barely $20 \%$ in the Boeing B787 [11]. Comparisons of tensile modulus and strength characteristics of E-glass fibers (72 GPa, 3.5 GPa) against $\mathrm{Al}(68.9 \mathrm{GPa}, 0.31 \mathrm{GPa})$ offer another explanation for the tendency toward composites [11].

\subsubsection{Automotive}

Because their light weight allows for the maximum possible performance, composites have been utilized in sports vehicles. Electric propulsion and self-guiding technologies have been made possible by recent advancements in mobility. These vehicles require lightweight materials to achieve higher ranges between recharging (i.e., electric automobiles), which has driven the need for high-volume composite manufacturing and EoL disposal. Another driving force behind the push for recycling is the fact that the automobile and aerospace industries, which produce large quantities of carbon fiber parts, also waste large percentages of the raw materials used (sometimes as much as $20-40 \%$ ). One of the goals of the automobile industry is to have vehicles that are both fuel-efficient and lightweight. The use of CFRC in automotive components decreases the weight of a typical vehicle by $30 \%$ [2]. The importance of environmental stewardship cannot be overstated. EU law in the automobile sector mandates that $85 \%$ of a car can be recycled. CF scrap may be collected and transformed into new components with less than $10 \%$ of the energies used to manufacture virgin carbon fiber $(\mathrm{CF})$, meeting legal and environmental goals [2]. CFRC help to reduce greenhouse gas emissions by reducing fuel usage, since they are utilized to make lighter automobile and airplane bodies [2]. Cost reduction is a significant motivator in the composites field [12].

\subsubsection{Marine}

Composites have proven to be a game-changer in the offshore business. At present, glass fiber (GF) and carbon fiber (CF) composite materials play a huge role in marine energy development, shipbuilding, and marine engineering repair. Composite materials have slowly and steadily replaced upper metal (above water level) in more and more marine installations, whether new installations or in renovations of existing structures. Carbon fiber has several advantages in marine engineering construction [13-17], including lighter weight, high strength, and wear resistance. Most installations use structural parts to replace traditional building materials, reducing the high freight weight, seawater corrosion, and the problems arising from rebar materials [18,19]. The following are the primary advantages of GRP for maritime applications: environmental resistance, durability, costeffectiveness, the ability to mold complex, seamless objects, the ability to adjust strength to load circumstances, excellent strength-to-weight ratio, light weight (about half that of similar steel constructions), low maintenance/repairability, and excellent long-term durability $[18,19]$.

\subsubsection{Wind Energy}

Composites are used in wind turbines because of their high specific strength. According to the GWEC, the total number of utility-scale wind turbines installed throughout the world has surpassed 330,000, most of which are projected to last 20-25 years. The first significant group of wind turbines made of composite materials will approach their EOL in the 2020s [20]. As a result of the approaching challenge of recycling wind turbine blades, roughly two gigawatts are expected to be replaced in 2019 and 2020 [21]. Denmark, for example, was a significant participant in the initial implementation of wind turbines, and has now become one of the first countries to tackle the mass disposal problem [20]. Some EU nations have prohibited the disposal of composite blades in landfills for environmental 
reasons [4], necessitating the development of novel EOL solutions for composites in this industry. The used scrap blade materials are anticipated to double in the next decade, from $1,000,000 \mathrm{t}$ in 2020 to 2,000,000 $\mathrm{t}$ in 2030 [22]. An estimated $25 \%$ of all EOL trash will be generated in the EU, according to estimates [12].

The majority of turbine rotors feature three blades, with sizes ranging from $12 \mathrm{~m}$ to $80 \mathrm{~m}$ or more. Several of these blades are expected to be phased out shortly [20]. Siemens Gamesa Renewable Energy (SGRE) has a capacity of 14 MW wind turbines with Integral Blades that are $108 \mathrm{~m}$ long. The radius of the rotor is $111 \mathrm{~m}$. As we enter the 2020s, recycling will become increasingly important. Nowadays, about $90 \%$ of the entire mass of wind turbines is recyclable, and the wind energy sector uses about 2.5 million tons of composite material worldwide [4]. Furthermore, by 2023, about 14,000 blades (weighing $40,000-60,000$ tons) will be decommissioned. The wind industry prioritizes the recycling of these obsolete blades [4]. For disassembly, collecting, transportation, waste disposal, and restructuring of composite materials into production chains, this challenge requires both logistical and technical solutions [4].

\subsubsection{Construction and Infrastructure}

Perhaps the most intriguing application of sophisticated composite materials so far is a functional bridge on the state highway system. Hollow carbon composite tubes and lightweight concrete were employed in its construction. ACMs are excellent for seismic retrofitting because of their flexibility and ease of application. They are now a valuable resource for retrofitting and improving processes in forensic engineering. Glass and carbon fibers are most commonly used in epoxy resin matrixes [23].

Additionally, after wind turbines, WPCBs are one of the fastest-growing worldwide waste sources, accounting for a major portion of overall electronic waste and containing 27.4-45.55 wt $\%$ GF. Owing to the existence of hazardous metals and organic substances, as well as GFs, the recovery of WPCBs to retrieve GFs is a difficult procedure [7,22].

Composite material recycling will become more important in the 2020s and beyond as efforts are made to cut down on pollution and fulfill demand. Figure 2 shows the global composite materials' market size distribution by application in 2020.

- Others
- Consumer goods
- Construction
- Pipe and tank
- Aerospace
- Wind energy
- Marine
- Transportation

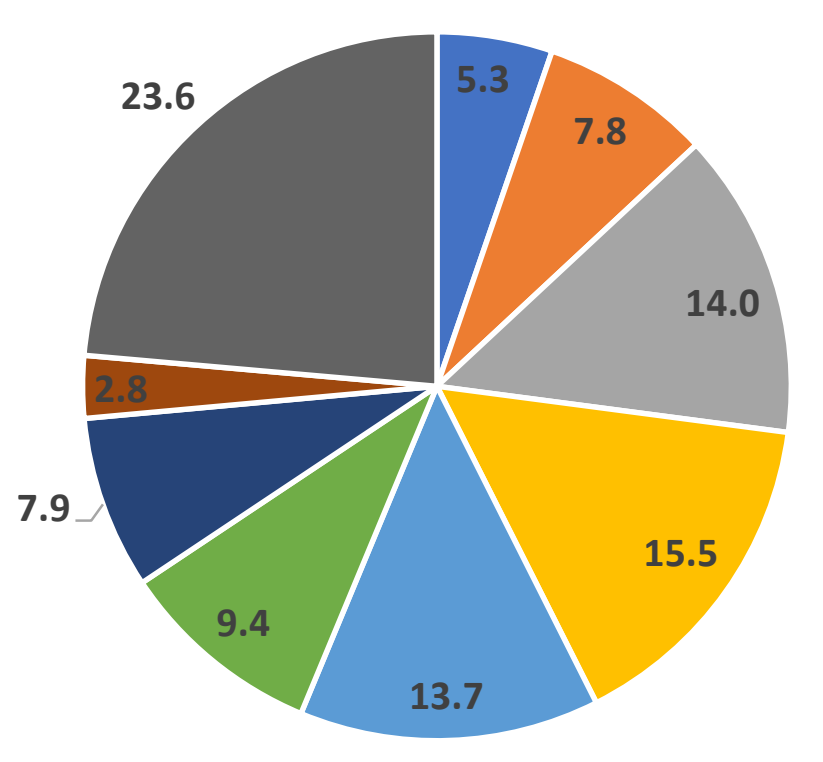

Figure 2. Global composite materials' market size distribution, by application, in 2020 [2]. 
Among composite materials, fiber-reinforced composites (FRC) are the most widely utilized [24-28]. The remarkable material characteristics of CFRC and GFRC make them particularly useful in this regard [29-32]. FRC materials are attractive as a replacement for steel and other materials due to their low weight, high strength, durability, and form flexibility. CF and GF, with polyester matrix resin as components, were used to create modern FRC materials in the early 1950s. They're commonly utilized in the construction of boats, automobiles, and storage tanks [30]. The international market for composite materials is growing and is estimated to exceed $\$ 96$ billion in 2020, up 40\% from 2014. Carbon and glass fibers are the most common materials; CFRC and GFRC products account for $\$ 57$ billion and $\$ 30$ billion, respectively, of the $\$ 96$ billion [2].

The FRC industry's expansion has boosted both productivity and consumption. However, it has also resulted in a large number of EOL materials. The struggle to preserve and recycle EOL scrap FRC has become a major barrier to the sustainability of a circular economy. In the past, the industry rushed to use these materials without understanding how to properly dispose of them. For decades, the two most common disposal techniques used by the composite industry were landfill and incineration. The drawbacks of these techniques have led to increased environmental awareness, resulting in the search for sustainable disposal methods and strategies to avoid trash accumulation [33-39].

Over the past few years, several studies have analyzed market demand for various composites, as well as the associated quantity of accumulating waste, in order to minimize the unavoidable negative effects. The market for fiber-reinforced polymer composites (FRPC) in the United States was about $\$ 12$ billion in 2020, with a yearly growth rate of $6.6 \%$ [40,41]. To meet such a high need for virgin carbon fiber (vCF) and virgin glass fiber (vGF), the accumulating CFRC and GFRC waste must be recycled effectively, to minimize environmental consequences while also meeting the demand [42]. However, converting CFRP and GFRP into useful resources is a difficult problem that threatens the future of the fiber-based industry [43-46].

As a result, the treatment and recycling of FRC materials such as CFRC/GFRC within environmental constraints, government regulations, manufacturing costs, resource management, and economic opportunity are all critical worldwide problems. The present research demonstrated the influence of the pyrolysis technique as a rising and feasible technology for FRC recycling. This research will help to systematize technological knowledge of CFRC/GFRC recycling processes such as pyrolysis.

Several researchers have dealt with the topic of recycling FRC materials. Krauklis et al. tried to create clear standards for economically and ecologically viable EOL solutions and fiber-reinforced composite material recycling [1]. Oliveux et al. examined the life cycle assessment of composite materials, as well as the economic and environmental implications of recycling them [25]. Naqvi et al. presented the strong link between recycling and reusability of fibers, which helped to illustrate the idea of the circular economy and cradle-to-cradle strategies [40]. Gharde et al. listed mechanical, thermal, and chemical recycling methods, as well as their efficacy in degrading large amounts of FRP materials [3]. Moreover, Liu et al. devised a technique for deconstructing, recycling, and remanufacturing composite materials that are both sustainable and cost-effective [7]. Pickering et al. examined thermoset composite recycling systems and detailed some of the major work in the fields of mechanical and thermal recycling [46]. According to Job et al., GF/CF plastics (GRP and CFRP) offer outstanding characteristics, but they also found that a lack of recycling programs was a barrier to their wider usage [6].

The conventional narrative review structure was used in this study. The Scopus database was primarily used for a complex literature search, with three other databases (Web of Science, Science Direct, and Research Gate) serving as supplementary support platforms. The search was restricted to the previous 20 years, with a focus on recent papers (the last ten years). Keywords used in searches included "carbon fiber", "glass fiber", "pyrolysis", “CFRC", "CFRP", “FRC", “GFRC", "GFRP”, "composite recycling", "waste composite", and "thermal recycling". Finally, suitable papers were carefully chosen 
based on an examination of the title, goal, and original results obtained. Fiber-reinforced composites (FRC) are the most frequently used composite materials in main applications; as a result, the selection focused on CFRC and GFRC.

Furthermore, utilizing Microsoft Excel, all of the related papers on the recycling of CFRC waste (410 papers) and GFRC waste (120 papers) were evaluated and organized into a private database. The selection was further refined based on the following criteria: a focus on thermal recycling technologies, particularly Pyrolysis techniques; and the impact on the environment, economic valuation, recycled fiber quality, and industrial reusability. Publications that did not meet the outlined selection criteria were removed. Consequently, the scope of this literature analysis was restricted to include just the most important pyrolysis-based approaches for recycling CFRC and GFRC waste. The necessity to replace virgin fibers with recycled fibers was also supported by emphasizing the associated process parameters and the characteristics of the resulting fibers. The final reference list included 114 publications.

This review provided a summary article detailing known ways for recycling accumulating composite scraps, comprising carbon and glass fiber. The focus was on the use of thermal recycling technologies, particularly Pyrolysis techniques, for recovering fibers and determining their preserved characteristics. Pyrolysis approaches were prioritized in the study on the basis of the following criteria: the impact on the environment, economic valuation, recycled fiber quality, and industrial reusability. The research also emphasized the accompanying process parameters and the properties of the resultant fibers in order to support the need to replace virgin fibers with recycled fibers. Additionally, the current study revealed gaps and recommened possible solutions.

This work is well-structured and separated into sections as follows. An overview of the various recycling options can be found in Section 2. Section 3 shows how to recover CFRC/GFRC using the pyrolysis technique. Pyrolysis products and their reuse are described in Section 4. The research gaps are then explored in Section 5, reviewing the current study effort on recycling CFRC/GFRC, utilizing the promised approach of pyrolysis. Finally, in Section 6, the article ends with the authors' conclusions.

\section{Review of Recycling Technologies}

Several publications have documented several techniques of CFRC/GFRC for prospective industries over the last 10 years. The most common ways of recycling composite material are mechanical, thermal, and chemical recycling [25]. Thermal recycling methods were detailed in depth in this study along with the economic potential and environmental effects of the techniques.

Heat is utilized to break down scrap composite during thermal recycling. The minor volatile elements are likely burned away due to the increased working temperature $\left(450-700{ }^{\circ} \mathrm{C}\right)$, leaving only the valued fibers. The temperature is usually determined by the kind of resin used in the waste composite. An inappropriate temperature might result in char on the fiber (undercooking) or a decrease in the thickness of the fibers (overcooking) $[25,45]$. As illustrated in Figure 3, thermal recycling may be divided into three categories [46].

The underlying idea for utilizing heat to decompose scrap composite remains the same; however, the outcomes vary depending on the method. Due to the calorific values of polymeric compounds, electricity may be produced by turning scrap composites into heat $[24,25]$. On the other hand, the ash byproduct of the combustion (incineration) process is a significant disadvantage, since it can only be landfilled as inert waste, at a cost that varies from country to country. In France, for example, its cost is about $92 € /$ ton. This complexity stymies the circular economy's growth. Furthermore, while converting heat to electricity, no more than a 35\% efficiency rate is attainable. Generally, burning coal rather than incinerating CFRP is a far superior alternative. Complete fiber recovery utilizing thermal techniques - such as the fluidized-bed process (FBP) or pyrolysis-have been the subject of recent research [47]. 


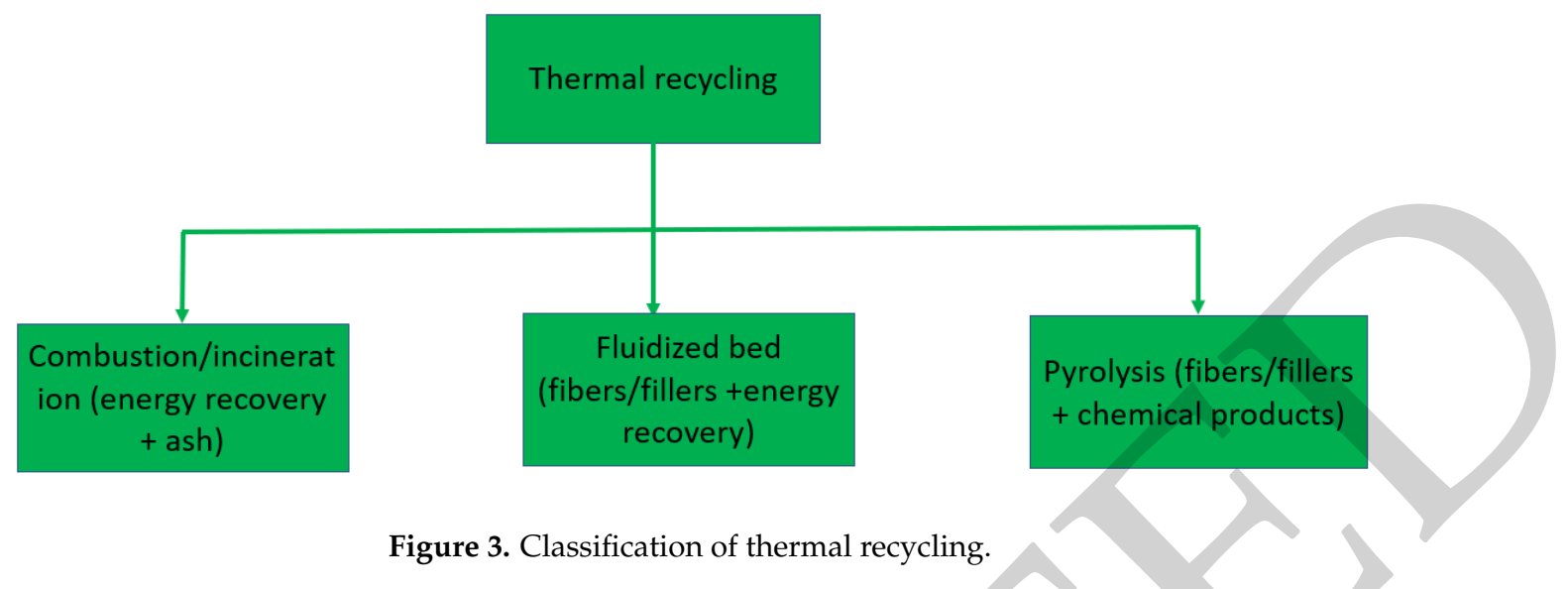

Rather than complete incineration of CFRC, management of resin breakdown, at the right temperature, would yield CF with minimal surface harm. Rodrigues et al. thermally decomposed resins for two hours at a temperature of $450{ }^{\circ} \mathrm{C}$ and recovered the $\mathrm{CF}$ without significantly compromising their surface properties [45]. Because of its cross-linked construction, degraded epoxy resin is difficult to recycle. As a result, recycling with minimal surface damage is a preferable alternative to fully landfilling. Although resin decomposition utilizing thermal techniques is not as suitable for GF as it is for CF, chemical treatment of rGF aids in the recovery of characteristics, to an extent [48]. When GF is thermally recycled at high temperatures $\left(300-600{ }^{\circ} \mathrm{C}\right)$, it loses up to $80 \%$ of its strength, making it hard to recover because of its poor reinforcing potential $[49,50]$. Yang et al. explored chemical etching and post-sanitation to treat degraded GF. In rGF, the chemical treatment restored 30-70\% of the loss of the mechanical characteristic [49]. By soaking the GF in a $\mathrm{NaOH}$ for $10 \mathrm{~min}$ at $90^{\circ} \mathrm{C}$, and then neutralizing it with HLC, Thomason et al. were able to restore $75 \%$ of the strength loss. The procedure used in their study is called short-hot sodium hydroxide solution therapy [48]. Pender and Yang [51] used catalysts such as $\mathrm{CuO}$ and $\mathrm{CeO}_{2}$ to speed up the breakdown of resin. Consequently, the process duration was cut by $20 \mathrm{~min}$, and energy usage was lowered by $40 \%$. The most efficient method used $\mathrm{CuO}$ at $375{ }^{\circ} \mathrm{C}$ to remove resins, whereas $\mathrm{CuO}$ and $\mathrm{CeO}_{2}$ improved the strength retention of GF by $20 \%$.

Fast, hot air was conducted across the conventional fluidized bed process (FBP). Typically, a bed of $0.85-\mathrm{mm}$-sized silica sand is utilized, which is subsequently transformed into a fluidized bed by flowing air at $0.4-1.0 \mathrm{~m} / \mathrm{s}$. The waste composite divides into fibers and fillers (volatile chemicals) inside a fluidized bed, which are transported out as individual particles by the air stream [46,52]. Furthermore, using a high-temperature $\left(1000^{\circ} \mathrm{C}\right)$ secondary chamber causes the volatile chemicals to be oxidized, leaving the fibers alone $[46,52]$. The method can recover both CF and GF, and it's very good for recycling EOL waste composites [25]. However, constraints, such as fiber strength and length deterioration, were apparent throughout the process's early development. In addition, the fibers obtained using this method are puffy [29].

Pickering et al. [52] demonstrated the limits when they studied the capacity of FBP to recover GF and obtained $67 \%$ fiber output. Moreover, the procedure only kept $50 \%$ of the rGF's tensile strength, compared to vGF. The research also added a financial estimation for commercializing the method, which predicted a net yearly profit of 0.002 million dollars for $9000 \mathrm{t}$ per year. In contrary to Pickering et al. [52], Zheng et al. [53] reported having developed a unique FBP method for recycling WPCBs, claiming to have achieved a $94.8 \mathrm{wt} \%$ and $95.4 \mathrm{wt} \%$ GF recovery and purity rate, respectively. Other than the fact that, in their method, the WPCB were coarsely chopped, rather than standard cutting size $(25 \mathrm{~mm})$, the recycling technique appeared to be almost the same. However, SEM image observations were used to confirm the findings. Furthermore, no information about the rGFs' strength was provided. Pender and Yang [54] utilized $\mathrm{CuO}$ to increase the production of rGF, with the yield increasing from 59 to $70 \%$. 
Yip et al. [55] conducted research identical to Pickering et al. [52], using CF instead of GF. When compared to GF recycling, the data revealed that recycling CF under the same circumstances was significantly more effective. The length of the rCF was determined by the initial length of the CF waste, according to the research and, given the non-uniform orientation, a fiber length of 5.9-9.5 mm could be recovered. Pickering et al. [56] built a commercial-scale FBP, in line with prior research. The rCF only lost $18.2 \%$ of its tensile strength and had no tensile modulus loss. According to the research, when compared to any other rCF utilizing FBP, this design showed the greatest efficiency. Furthermore, the energy required to obtain CF from FBP was approximately $5-10 \%$ of the energy required to produce vCF.

Other researchers $[25,29,46]$ thoroughly described and analyzed the technical comparability and reuse applications of three recycling techniques. Their findings indicated that the thermochemical technique was suitable for CFRC recycling, due to the rising cost of CF for high-grade applications like aerospace and structure industries. The mechanical method was suggested as a preferable method for GFRC due to the low cost of vGF $[25,57]$. Wong et al. [58] compared the power consumption of the chemical, thermochemical (incineration and pyrolysis), and mechanical techniques. The power consumed during pyrolysis (30 MJ/kg) was reasonable, as shown by this study, when compared to other frequently used industrial applications. Mechanical separation, incineration, gasification, and slower pyrolysis (i.e., in a kiln), on the other hand, were either costly or yielded low characteristic fibers. Pyrolysis seemed, thus, to be a realistic and promising approach for efficient recovery and high characteristic fiber production. The essential pyrolysis technique variables, their influence on fiber characteristics, and the utilization of recovered fiber were highlighted in this paper. The present study identified gaps, and a proposal was presented.

The University of Nottingham in the United Kingdom devised a low-temperature $\left(450{ }^{\circ} \mathrm{C}\right)$ incineration method in an FBP for the recycling of FRC $[46,52,53]$. This method recovered fibers while also generating gas for energy recovery. Mixed and polluted materials can be treated in fluidized-bed reactors. This technique, conversely, necessitated large quantities of high-temperature air and resulted in a decrease in fiber characteristics (particularly for GF) due to mechanical activity in the bubbling sand bed. The value of recovered fibers is an essential consideration in this procedure. Fiber has a high intrinsic value owing to its large price as a virgin substance, but the high labor costs involved and the large quantity of energy required undermine the economic case for recycling operations utilizing a low-temperature incineration FBP. In aeronautical applications, a combination thermolysis and gasification method for recovering scrap CFRC was employed [59]. However, the gasification period was too lengthy, resulting in unfavorable changes in the atomic composition of the CF. The most researched thermal technique for recovering CF/GF composite waste is pyrolysis in an inert environment [60-62]. To guarantee effective and maximal recovery of fiber and fuels, as well as chemical synthesis, pyrolysis processes (slow or rapid) need optimum conditions [63-66]. According to the authors' knowledge, no detailed study of carbon/glass fiber recovery utilizing the pyrolysis technique has yet been published. The current research not only covered the essential elements of the pyrolysis technique but also emphasized the influence of technique variables on fiber recovery and fuel generation.

\section{Recovery of CFRC/GFRC Utilizing Pyrolysis}

Both CF and GF may be recycled efficaciously using this method [40]. The scrap composites are heated in the absence of air, unlike previous thermal recycling methods. The disintegrating matrix generates oil and gas, as well as fibers and fillers (solid products) $[25,46]$. The working temperature for a typical FRC varies between 400 and $700{ }^{\circ} \mathrm{C}$, depending on the composition of the waste composite [24,29]. The oil that results is aromatic and has a heating value of $37 \mathrm{MJ} / \mathrm{kg}$, which is comparable to fuels. The pyrolysis reactor may be renewed with the gas produced. The liquid and gas generated can be used as a chemical feedstock in a variety of processes. Despite all of this, the technique 
can preserve fibers with superior mechanical characteristics [24,29]. Pyrolysis is the best researched thermal recycling method [25], and a flowchart of the process is shown in Figure 4 .

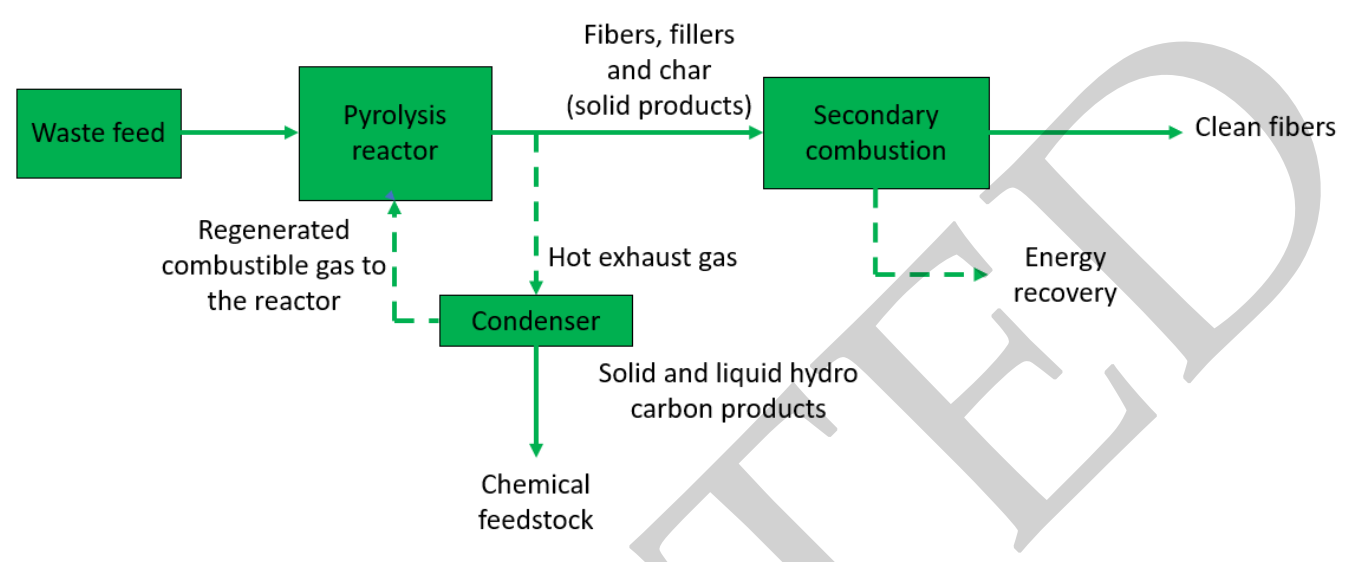

Figure 4. Pyrolysis process [46].

Pyrolysis, like any other recycling process, has several drawbacks, the most problematic of which is the probability of char development on the resultant fiber surface [29]. Due to the char, the mechanical characteristics of the recovered fibers can be substantially decreased. Chemical treatment $[27,28]$ and post-heating treatment of the fibers both help to reduce char formation, but only to a limited extent $[67,68]$. Carbon dioxide $\left(\mathrm{CO}_{2}\right)$ and water vapors have been utilized to eliminate char formation from CFRC in recent research [69]. Additionally, oxidizing the fiber surface results in the development of a surface with high levels of oxygen, which improves the fiber's adhesiveness with resins [70].

The UK milled carbon group was successful in building and executing a commercialscale furnace with a controlled environment that can totally eliminate char development on the rCF $[29,62]$. Additionally, a German company (CFK) currently employs a continuous pyrolysis reactor. Both businesses recycle CFRC trash in different forms. They may also recover longer and cleaner CFs, thanks to the large furnaces and continuous flow [29]. Meyer et al. [60] demonstrated this phenomenon in previous research by recycling aircraft CFRC scrap, in which lab-scale pyrolysis was scaled up to industrial pyrolysis. Using a larger oven, the scientists were able to recreate industrial plant operations with $\mathrm{rCF}$, preserving $96 \%$ of its initial tensile strength. Although the $\mathrm{rCF}$ was sufficient to replace $\mathrm{vCF}$, a supplementary combustion chamber was developed to remove the leftover char. Overall, the process results could be influenced by a regulated environment in the pyrolysis reactor.

\subsection{Pyrolysis: Controlled Atmospheres}

To extract fibers from solid pyrolysis products, sophisticated, regulated air conditions were introduced with the development of pyrolysis technologies. Evidence of such approaches were shown in several works in the literature released since 2010. Pyrolysis' basic principle remained unchanged. Air conditions inside pyrolysis reactors, on the other hand, have been continually changing to achieve greater yields. In pyrolysis, typical atmospheric conditions include nitrogen, vacuum, and superheated steam.

\subsubsection{Vacuum Atmosphere}

Organic vapors' residential period within a vacuum pyrolysis reactor is reduced because of the low degradation temperature that is adequate to recover GF without disrupting surface quality $[71,72]$. VP was evaluated as a replacement for the mechanical technique by Zhou and Qiu, and used to recycle WPCBs [71]. vacuum pyrolysis (VP) was judged as an alternative approach to mechanical recycling. The liquid and gas products (can be used as chemical feedstock) along with solid products (GF and metal components) were found to increase the interests of researchers when compared to mechanical recycling [71-73]. 
The researchers used a two-step pyrolysis technique to extract GF from WPCBs, using VP and VCS. Long et al. [73] utilized VP to separate the GF from metal portions, utilizing GS and nonmetal portions and a calcination procedure. There was no examination of the mechanical characteristics of rGF in that research, which focused on recycling WPCBs in a vacuum environment. Table 1 lists the process' yields. Due to the lack of relevant research on $\mathrm{CF}$, this procedure was confined to GF alone.

\subsubsection{Nitrogen Atmosphere}

Pyrolysis in a nitrogen environment-unlike vacuum pyrolysis-may recycle both CFRC and GFRC [62]. Until Zhou et al. [72] published their work in 2010, the most common pyrolysis technique used to recycle WPCBs was pyrolysis under nitrogen atmosphere (NA). WPCBs were recycled via vacuum pyrolysis, resulting in a maximal rGF. After studying the benefits of NA, Onwudili et al. [74] improved the method and succeeded in recycling CFRC scrap, recovering $98 \%$ of $\mathrm{rCF}$. According to the study, a rise in reaction time may have resulted in a reduction in the mechanical characteristics of $\mathrm{rCF}$. The inadequate reaction time may also have resulted in the formation of char on the fibers. Table 1 shows the yield from the procedure.

In 2016, Onwudili et al. [62] used NA with a semi-batch reactor to investigate the mechanical characteristics of both recycled CFRC and GFRC waste. Chemical alterations of the surface of rCF and rGF fibers may have improved fiber characteristics, according to the study. Secondary combustion (SC) was also utilized in both experiments $[62,74]$ to oxidize the char on the pyrolyzed fibers. When analyzing the findings, it was discovered that oxidized fibers preserved the highest mechanical characteristics, compared to nonoxidized fibers.

\subsubsection{Superheated Steam Atmosphere}

In most cases, the steam is created by heating saturated steam at a steady pressure. To attain superheated levels, the steam is heated many times over its saturation point during the transition period. In pyrolysis, using a superheated steam atmosphere improves heat transmission, which accelerates the thermal breakdown and supports the removal of oxygen from the pyrolysis reactor [75]. In comparison to other pyrolysis atmospheres, recycling CFRC with superheated steam leads to high retention of CF mechanical characteristics [76-79]. Chemical treatments can also decrease a considerable percentage of char development on the resultant rCF and rGF [68].

Shi et al. [76] discovered that the $\mathrm{rCF}$ had a major quantity of char on its surface, which rendered the fibers unusable. According to the study, the higher the quality of $\mathrm{rCF}$, the lower the pyrolysis temperature. Shi et al. [68] expanded their earlier study to CFRC and GFRC, eradicating char on rCF and rGF utilizing chemical treatment. Using NMP, the bending strength rose from $49-78 \%$ for $\mathrm{rCF}$ and $26-94 \%$ for rGF. Using fast pyrolysis, Jeong et al. reported that $66 \%$ of the strength and $100 \%$ of the tensile modulus were retained after recycling CF [78].

Ye et al. [79] combined VP and mild gasification for recycling CFRC scrap to maintain maximal tensile strength (TS) for rCF. In both laboratory and semi-industrial sizes, the method preserved $90 \%$ of its TS. According to the study, an increase in degradation in the polymer matrix resulted in a drop in the TS of the fibers. Kim et al. [77] used an FBP at $550{ }^{\circ} \mathrm{C}$ for $60 \mathrm{~min}$ and preserved $90.42 \%$ of the TS. According to the study, increasing the steam temperature improved the elimination of char. Kim et al. [80] utilized superheated steam to eliminate minor resins with $\mathrm{CO}_{2}$, maintaining more than $80 \%$ of TS.

\subsection{Microwave Pyrolysis}

Microwave radiation is used to replace the traditional heating source in microwaveassisted pyrolysis. This modification enhances the heat transfer while consuming a minimum quantity of energy, without conflicting with the basics of pyrolysis. The method may recycle both CFRC and GFRC fibers while preserving greater mechanical character- 
istics [66]. Obunai et al. [81] removed all the resin after $300 \mathrm{sec}$ utilizing a $700 \mathrm{~W}$ with $2.5 \mathrm{~L} / \mathrm{min}$ argon environment. Tensile strength in the $\mathrm{rCF}$ was just $0.7 \%$ lower than in the vCF. Similarly, Jiang et al. [82] recycled CFRC for $30 \mathrm{~min}$ at $500{ }^{\circ} \mathrm{C}$ using a $0.70 \mathrm{~m}^{3} / \mathrm{min}_{2}$. The rCF had a clean fiber surface and mechanical characteristics similar to vCF.

\subsection{Pyrolysis on Wind Turbine}

Pyrolysis was commonly favored in studies concentrating on GF recovery from wind turbines [83-86]. Aside from basic GF recycling, research has concentrated on maintaining mechanical characteristics to utilize them in a variety of different applications [26].

Several researchers were successful in preserving $75 \%$ of rGF TS by employing the microwave method in NA [85-88]. Their research claimed that a reduction in TS could be compensated by recycling it as a hybrid composite, mixing rGF and vGF.

Other researchers emphasized limitations, stating that rGF from wind blades was discontinuous, thin, and randomly directed. Furthermore, the TS of rGF was lower than that of vGF $[83,84]$. Furthermore, other studies concluded that the wind blades would be useful for both energy and material recovery [26]. Current studies also emphasized that chemical recycling could be more efficient for the recovery of GF and CF from wind blades [34].

\section{Pyrolysis Products and Their Reuse}

As previously stated, the compromised fiber surface with char poses a challenge for reuse. To separate the fiber, low-temperature combustion and gasification procedures employ a considerable volume of hot air to eliminate the char. A post-pyrolysis treatment is required to purify the surface of the recovered fiber before it can be recombined to create a new composite. The treatment is accomplished by oxidization, carried out at a regulated temperature and residence duration. The optimum temperature and residence time are significant issues.

XPS is utilized to assess the surface properties of recovered fibers [88]. Surface characteristics may have an effect on interfacial bonding performance. Both the oxidizing (air) and thermal $\left(\mathrm{N}_{2}\right)$ atmospheres are important in determining surface properties. Surface defects have been discovered in oxidizing atmospheres, resulting in a decrease in TS and crystallite size. As a result, in order to allow a successful recycling process, a regulated and optimum temperature and residence duration in post-pyrolysis is advantageous [89].

Recycling CFRC/GFRC by pyrolysis has great potential, since it recovers the precious fibers and produces both gas and liquid products. A gas analyzer can be utilized to evaluate the gas mixture produced by the pyrolysis process. Because of the significant secondary cracking, the produced gas may be composed of, according to the literature, $\mathrm{H}_{2}, \mathrm{CH}_{4}, \mathrm{CO}$, and $\mathrm{CO}_{2}$. The quantity of these gases is mostly determined by the pyrolysis mode (slow or rapid), temperature, and residence duration. Additionally, researchers discovered that the breakdown of oxygen-rich components contained in the resin formulation produce carbon oxides in greater concentrations at higher temperatures. The produced liquid is mostly aromatic. The major components of the organic fraction were detected by GCMS as ethylbenzene, benzene, styrene, toluene, and p-xylene. Aside from aromatics, pyrolysis oil contains oxygenated species [88-92]. The major gaseous and oil components are summarized in Figure 5. 


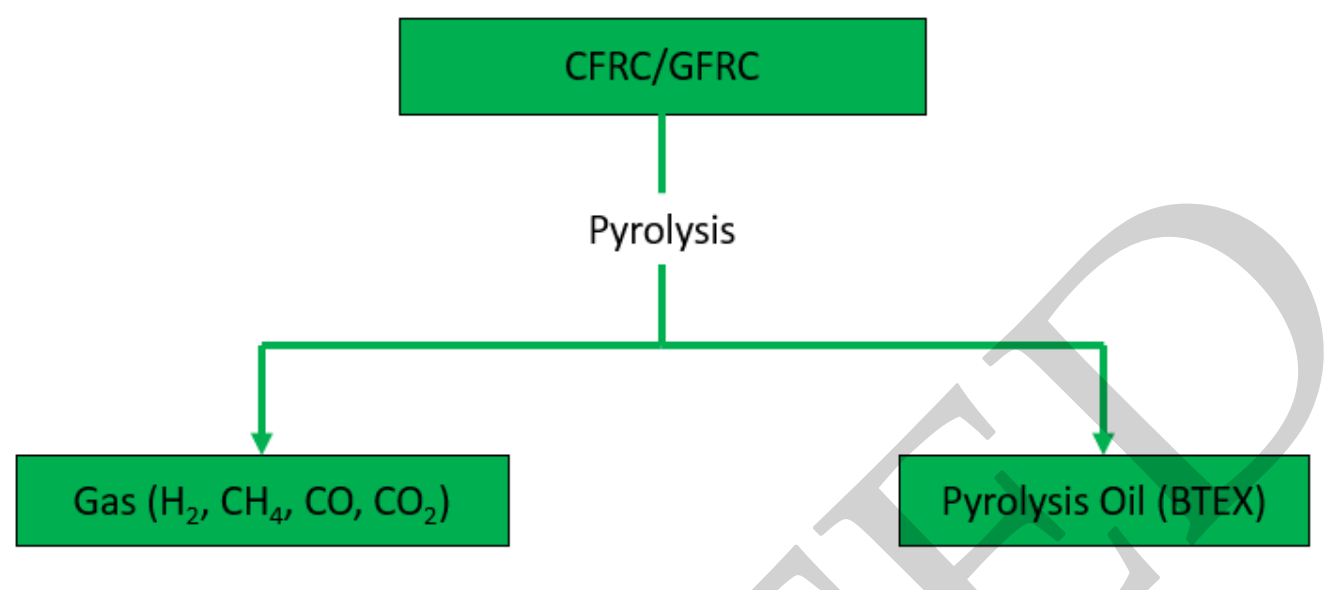

Figure 5. Major oil and gas products from pyrolysis of CFRC/GFRC [88-92].

TGA was frequently utilized to evaluate breakdown behavior [90]. TG and DTG graphs demonstrated the mass loss of the resin with increasing temperatures. According to published research, the breakdown temperature of the resin was complete between $450-500{ }^{\circ} \mathrm{C}$ in the case of GRFC [91,92], while CFRC breakdown temperatures were between $450-600{ }^{\circ} \mathrm{C}$ depending on kind and whether the materials were cured or uncured $[77,93]$. For post-pyrolysis in air atmosphere, $500-600{ }^{\circ} \mathrm{C}$ was found to be the optimal temperature for oxidizing char and cleaning the fiber surface [59,77]. In comparison to virgin material, attenuated total reflection, combined with FTIR, proved to be a reliable technique for identifying functional groups existing on recovered fibers [94]. To maximize the effect of the recycling process, mechanical characteristics were measured [95-97]. SEM, Raman, and XPS studies were used to examine the morphology of the retrieved fibers. Image analyses for fiber length [10] and micro-bond testing for interfacial adhesion among various pyrolysis parameters for recovered fibers and polymers [73] were used for additional studies. Table 1 shows the yield from the procedure. 
Table 1. GF and CF recovery from composites by Pyrolysis.

\begin{tabular}{|c|c|c|c|c|c|c|c|c|c|}
\hline \multirow{2}{*}{ No. } & \multirow{2}{*}{ References } & \multirow{2}{*}{ Material } & \multirow{2}{*}{ Reactor } & \multicolumn{3}{|c|}{ Pyrolysis Products (wt \%) } & \multirow{2}{*}{ Application } & \multirow{2}{*}{ Process Parameters } & \multirow{2}{*}{$\begin{array}{l}\text { Oxidation } \\
\text { Treatment }\end{array}$} \\
\hline & & & & Solid & Liquid & Gas & & & \\
\hline 1 & Onwudili et al. [62] & CF from reinforced thermosets & $\begin{array}{l}\text { Lab-scale } \\
\text { batch } \\
\text { reactor }\end{array}$ & 73.1 & 23.8 & 2.3 & Commercial LDPE & $\begin{array}{c}\mathrm{N}_{2}: 5 \mathrm{dm}^{3} / \mathrm{h} \\
500{ }^{\circ} \mathrm{C} \\
45 \mathrm{~min}\end{array}$ & $500^{\circ} \mathrm{C}$ \\
\hline 2 & Onwudili et al. [62] & GF from reinforced thermosets & $\begin{array}{l}\text { Lab scale- } \\
\text { batch } \\
\text { reactor }\end{array}$ & 65.9 & 5.7 & 8.4 & Commercial LDPE & $\begin{array}{c}\mathrm{N} 2+\mathrm{SC}: 500{ }^{\circ} \mathrm{C}, \\
30 \mathrm{~min} \\
20^{\circ} \mathrm{C} / \mathrm{min} \\
\end{array}$ & $500^{\circ} \mathrm{C}$ \\
\hline 3 & Onwudili et al. [74] & $\begin{array}{l}\text { Carbon reinforced composite } \\
\text { plastic }(\mathrm{CRCP})\end{array}$ & $\begin{array}{l}300 \mathrm{~mL} \text { mini } \\
\text { autoclave reactor }\end{array}$ & $72-77$ & $22-25$ & $2-4$ & & $\begin{array}{rl}\mathrm{N}_{2}: & 400-500{ }^{\circ} \mathrm{C}, \\
& <30 \mathrm{~min} \\
\mathrm{SC} & 450{ }^{\circ} \mathrm{C}, 2 \mathrm{~h} .\end{array}$ & $450^{\circ} \mathrm{C}$ \\
\hline 4 & Meyer et al. [60] & High tenacity $\mathrm{CF}$ & Lab scale TGA & - & & & Aerospace & $\begin{array}{c}\mathrm{N} 2:(60 \mathrm{~mL} / \mathrm{min}), 900{ }^{\circ} \mathrm{C}, \\
10^{\circ} \mathrm{C} / \mathrm{min}\end{array}$ & $\begin{array}{c}600{ }^{\circ} \mathrm{C} \\
60 \mathrm{~cm}^{3} / \mathrm{min}\end{array}$ \\
\hline 5 & Giorgini et al. [92] & GF from laminates waste & Batch reactor & $40-45$ & $35-40$ & $15-20$ & & $\begin{array}{l}500-600^{\circ} \mathrm{C} \\
150 \mathrm{~min}\end{array}$ & $\begin{array}{l}500 \text { or } 600 \\
{ }^{\circ} \mathrm{C} 10 \text { to } 60 \\
\min \end{array}$ \\
\hline 7 & Zhou and Qiu [71] & WPCBs (GF) & A lab-scale reactor & 75.7 & 20 & 4.3 & - & $\mathrm{VP}: 600^{\circ} \mathrm{C}, 30 \mathrm{~min}$ & - \\
\hline 8 & Zhou et al. [72] & WPCBs (GF) & lab-scale reactor & 72.2 & 21.45 & 6.35 & - & $\begin{array}{c}\text { VCS: } 400{ }^{\circ} \mathrm{C}, 1200 \mathrm{rpm}, \\
6-10 \mathrm{~min}\end{array}$ & - \\
\hline 9 & Bradna and Zima [98] & Epoxy resin with CF & Py-GC/MS & - & - & - & - & $700^{\circ} \mathrm{C}$ & \\
\hline 10 & $\begin{array}{l}\text { Nahil and Williams } \\
\text { [99] }\end{array}$ & $\begin{array}{c}\text { Polybenzoxazine resin with } \\
\text { woven CF }\end{array}$ & $\begin{array}{l}\text { Static bed batch } \\
\text { reactor }\end{array}$ & $70-83.6$ & $14-24.6$ & $0.7-3.8$ & $\begin{array}{l}\text { Activated carbon } \\
\text { fibers }\end{array}$ & $\begin{array}{c}\mathrm{N}_{2}: 350-700{ }^{\circ} \mathrm{C}, \\
60 \mathrm{~min}, 5^{\circ} \mathrm{C} / \mathrm{min}\end{array}$ & $500^{\circ} \mathrm{C}$ \\
\hline 11 & Long et al. [73] & WPCBs (GF) & - & 74.7 & 15 & 10.3 & - & $\begin{array}{l}\text { (1) VP: } 550{ }^{\circ} \mathrm{C}, 120 \mathrm{~min} \\
\text { (2) GS + calcination: } 600{ }^{\circ} \mathrm{C} \text {, } \\
10 \mathrm{~min}\end{array}$ & - \\
\hline 12 & Greco et al. [100] & Cured CF & - & - & - & - & Aeronautic & $550^{\circ} \mathrm{C}, 20 \mathrm{~min}$ & $\begin{array}{l}550^{\circ} \mathrm{C} \\
90 \mathrm{~min}\end{array}$ \\
\hline
\end{tabular}


Table 1. Cont.

\begin{tabular}{|c|c|c|c|c|c|c|c|c|c|}
\hline \multirow{2}{*}{ No. } & \multirow{2}{*}{ References } & \multirow{2}{*}{ Material } & \multirow{2}{*}{ Reactor } & \multicolumn{3}{|c|}{ Pyrolysis Products (wt $\%$ ) } & \multirow{2}{*}{ Application } & \multirow{2}{*}{ Process Parameters } & \multirow{2}{*}{$\begin{array}{l}\text { Oxidation } \\
\text { Treatment }\end{array}$} \\
\hline & & & & Solid & Liquid & Gas & & & \\
\hline 13 & Cunliffe et al. [101] & $\begin{array}{c}\text { (1) Thermoset polyester/styrene } \\
\text { resin with GF }(12 \%) \\
\text { (2) Thermoset polyester/styrene } \\
\text { resin with GF }(30 \%) \\
\text { (3) Phenolic resin with GF }(31 \%) \\
\text { (4) Phenolic resin with CF } \\
\text { (5) Epoxy resin with GF and CF } \\
(45 \%) \\
\text { (6) Polypropylene resin with GF } \\
\text { tape (75\%) } \\
\text { (7) Vinylester resin with GF } \\
\text { woven }(70 \%)\end{array}$ & Static-Bed reactor & $\begin{array}{c}38.3-82.9 \\
32.6 \\
84.4-94.3 \\
65 \\
65.3-81.7 \\
78.9 \\
83.4\end{array}$ & $\begin{array}{c}14.5-47.4 \\
64.1 \\
5.1-12 \\
30.4 \\
18-31.7 \\
20 \\
15\end{array}$ & $\begin{array}{c}2.6-14.4 \\
3.3 \\
0.6-4.6 \\
4.6 \\
0.2-3 \\
1.1 \\
1.6\end{array}$ & $\begin{array}{l}\text { Autombile, electric } \\
\text { and circuit board }\end{array}$ & $\begin{array}{c}\mathrm{N}_{2}: 200 \mathrm{~cm}^{3} / \mathrm{min} \\
350-800{ }^{\circ} \mathrm{C} \\
60 \mathrm{~min}\end{array}$ & $400-800^{\circ} \mathrm{C}$ \\
\hline 14 & $\begin{array}{l}\text { Cunliffe and Williams } \\
\text { [102] }\end{array}$ & $\begin{array}{l}\text { Commercial polyester/GF }(30 \%) \\
\text { automotive waste }\end{array}$ & Fixed Bed reactor & 303 & & 5.8 & Autombile & $\begin{array}{c}\mathrm{N}_{2}: 3000 \mathrm{~cm}^{3} / \min 450{ }^{\circ} \mathrm{C} \\
90 \min \end{array}$ & $\begin{array}{c}\text { Muffle } \\
\text { furnace } 450 \\
{ }^{\circ} \mathrm{C}\end{array}$ \\
\hline 15 & Stoeffler et al. [103] & Cured \& uncured CF & batch oven & - & - & - & Aerospace & $400^{\circ} \mathrm{C}$ & - \\
\hline 17 & López et al. [106] & $\mathrm{T} 300 / 3 \mathrm{k} \mathrm{CF}$ & pilot-scale & $58.4-61.5$ & $28.5-30.7$ & $10-10.9$ & - & $350-700{ }^{\circ} \mathrm{C}$ & $500{ }^{\circ} \mathrm{C}$ \\
\hline 18 & López et al. [107] & GF from Polyester fiber glass & $\begin{array}{c}\text { Thermolytic } \\
\text { reactor }\end{array}$ & 68 & 24 & 8 & Ceramic & $\begin{array}{c}550{ }^{\circ} \mathrm{C} \\
180 \mathrm{~min}\end{array}$ & $1450^{\circ} \mathrm{C}$ \\
\hline 19 & Yun et al. [91] & GFRP from the B & TGA & - & - & - & - & $\begin{array}{c}\mathrm{N}_{2}: 200 \mathrm{~mL} / \mathrm{min} \\
\mathrm{RT}-900{ }^{\circ} \mathrm{C} \\
5-20{ }^{\circ} \mathrm{C} / \mathrm{min}\end{array}$ & - \\
\hline 20 & Yun et al. [108] & the $B$ & $\begin{array}{l}\text { Batch Type } \\
\text { Pyrolyzer } \\
\text { Thermo Balance } \\
\text { Reactor } \\
\text { Wire Mesh } \\
\text { Reactor }\end{array}$ & $\begin{array}{c}- \\
- \\
20-80\end{array}$ & $\begin{array}{c}- \\
- \\
15-50\end{array}$ & $\begin{array}{c}- \\
- \\
5-15\end{array}$ & $\begin{array}{l}- \\
-\end{array}$ & $\begin{array}{c}\text { (1) } \mathrm{N}_{2}: 1 \mathrm{~L} / \min \\
500-900{ }^{\circ} \mathrm{C} \\
15^{\circ} \mathrm{C} / \min \\
\text { (2) } \mathrm{N}_{2}: 0.315 \mathrm{~L} / \min 500-800 \\
{ }^{\circ} \mathrm{C} \\
\mathrm{N}_{2}: 1 \mathrm{~L} / \min \\
\text { (3) } 600-10002,4,6,8 \text { and } 10 \mathrm{~s}\end{array}$ & $\begin{array}{l}- \\
-\end{array}$ \\
\hline
\end{tabular}


Table 2 summarizes the characterization methodologies used to investigate thermal, mechanical, and morphological evaluations of fibers.

Table 2. Characterization methods used in CFRC/GFRC recycling processes [40].

\begin{tabular}{cccc}
\hline Thermal Analysis & Mechanical Testing & Morphological Testing & Others \\
\hline TGA & $\begin{array}{c}\text { TS (MPa), E(MPa), } \\
\text { Elongation }(\%)\end{array}$ & SEM, AFM, XPS & $\begin{array}{c}\text { Adhesion, Micro bond, fiber pullout, Image analysis } \\
\text { for fiber length distribution }\end{array}$ \\
\hline
\end{tabular}

Recycling choices have a major influence on the assessment of mechanical characteristics of recovered fibers (CF/GF). Poor adherence (to recycled fibers and epoxy resins) has an impact on mechanical characteristics. Pyrolysis is the only technique that generates higher mechanical characteristics for recycled fibers and permits commercial-scale use, according to several studies $[24,25,29]$. To solve mechanical property concerns, pyrolysis should be controlled using a regulated temperature with quick heating rates, adequate residence duration, and appropriate raw material length (Table 3).

Table 3. Mechanical properties of rCF/rGF from pyrolysis of CFRC/GFRC.

\begin{tabular}{|c|c|c|c|c|c|c|c|}
\hline Reference & $\begin{array}{c}\text { Fiber } \\
\text { Output }\end{array}$ & TS (MPa) & E (MPa) & Elongation (\%) & Diameter & Stiffness & $\begin{array}{c}\text { Fiber Length } \\
(\mathrm{mm})\end{array}$ \\
\hline Onwudili et al. [62] & GF & 11 & 428 & - & - & - & - \\
\hline Stoeffler et al. [103] & $\mathrm{CF}$ & $\begin{array}{c}\text { 680-720\% } \\
\text { increase }\end{array}$ & $\begin{array}{c}680 \% \\
\text { increase }\end{array}$ & $5 \%$ inc & 6.5 & - & 5.6 \\
\hline Giorgini et al. [92] & GF & 14 & 530 & & - & - & - \\
\hline López et al. [106] & $\mathrm{CF}$ & $2537-2544$ & $210-220$ & 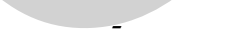 & $6.70-7.00$ & - & \\
\hline \multirow{2}{*}{ Nahil and Williams [99] } & \multirow{2}{*}{$\mathrm{CF}$} & $2340-3270$ & $230-233$ & $0.91-1.25$ & - & - & - \\
\hline & & 910-1250 & $182-233$ & $-\quad-$ & - & - & - \\
\hline Greco et al. [100] & $\mathrm{CF}$ & - & $8 \%$ reduction & - & 6.2 & $\begin{array}{l}14 \% \text { re- } \\
\text { duction }\end{array}$ & - \\
\hline
\end{tabular}

The poor market potential of recovered GF makes it unsuitable for high-value industries. Pyrolysis reduced the TS of the recovered CF by $5-10 \%$ as compared to combustion $(18 \%)$. However, additional study is needed to fully comprehend the mechanisms involved.

It is important to identify the material cost reductions that may be achieved by using rCF. rCFv are indeed cheaper than virgin fibers, but they are also inherently different from $\mathrm{vCF}$, which has restricted the entry of rCF into the vCF. Based on cost and performance, the task was to modify the material in such a way that virgin fiber can be replaced with recycled fiber.

In the case of carbon fiber composite materials, pyrolysis can result in fibers that are thin, discontinuous, and short in length. There were certain advantages to using these fibers; they were cost-effective, lightweight, with 3-dimensional complexity in the panels, and a secondary structure for airplane interiors [25]. Thermochemically converted recycled fibers demonstrated good mechanical characteristics compared to virgin fibers. When using the pyrolysis method, fiber strength was reduced by $10 \%$, compared to the combustion procedure, which resulted in a greater loss of strength at $50 \%$. The electrical conductivity of pyrolyzed recycled fiber was identical to that of vCF [109-111]. Some oxygenated species could still be found on the surface after recovery by pyrolysis, and fibers have been shown to bind effectively to epoxy resin [89] in terms of structure-property connection.

Reinventing composite constructions relies heavily on the fiber reclamation process for performance. A combination of resin and recovered fiber are compressed into pellets using direct- or injection-molding techniques. Nonwoven mats for lightweight composite manufacturing were made from milled fiber by ELG Carbon fiber in the United Kingdom [9]. Recycled carbon fiber products in automobile applications deliver lighter and stronger components at high volume manufacturing rates, while also allowing considerable cost 
savings. Nonaligned and short fibers tend to generate excellent quality, 3D complex, and lightweight constructions for components and panels with complex forms [112]. Recently, General Electric (GE) launched a bracket competition to enhance the extremely efficient bracket design $[113,114]$. The recovered nonaligned fibers have the potential to be part of improved lightweight products. For recycled fibers, there exists a broad variety of possible applications.

There are also myriad possibilities for market growth, e.g., nonwoven mats made from recycled carbon fibers, recycled carbon fibers mixed with thermoplastic fibers, chopped tow, and milled fiber. As part of a circular economy, carbon fibers are reused for as long as feasible and recovered for new composites and promising materials for practical uses.

It is the fiber reclamation process, which can supply high-quality fiber to produce new composites for intermediate commodities, that drives the usage of recovered fibers in a circular system. In contrast to low-value end-use, high-value end-use encourages the development of a sustainable supply chain for recovered fiber. With their 3D complex forms and discontinuous fibers, nonwoven mats with high fiber volume fractions in composites and minimal fiber breaking during molding can attain exceptional mechanical characteristics. While rCF may not be able to compete with vCF in terms of performance, competition is feasible in terms of weight reduction, cost reduction, and the ability to synthesize complicated shapes acceptable to certain automobile and parts sectors. The development of an efficient recovery process that can create high-quality fibers under moderate circumstances and reuse them in new composites is still in progress. Fibers produced using the pyrolysis process consist of short, discontinuous, fluffy fibers that have undergone a variety of procedures. Pimenta and Pinho introduced remanufacturing techniques [29]. The recovered fibers could be reused in different ways, based on their physical structure and mechanical characteristics, among other factors. Fiber alignment, fiber content, and fiber breakage reduction during processing still required technical development. A suitable, effective and low cost fiber recovery process in combination with suitable re-manufacturing process should be developed to reach the properties and performance of vCF. For technological demonstrations, Pimenta and Pinho emphasized, discontinuous, 3D-oriented fiber had the capacity to create secondary components for the automobile sector, as well as aircraft interiors and tools. When the residual char was removed from the recycled fibers, their mechanical characteristics were comparable to virgin substance, notably in the case of rCF [93].

Technical improvements in remanufacturing procedures are needed, notably in fiber alignment and fiber composition of new composites. The mechanical characteristics of recovered fibers-mixed with polymers to create new composites with qualities equivalent to the original CFRC—-play a major role in efficient recycling processes.

\section{Discussion}

Mechanical separation, incineration, gasification, and slower pyrolysis in a kiln, are costly or yield low characteristic fibers. Pyrolysis seems to be a realistic and promising approach because it is efficient in recovery and produces high characteristic fibers. The essential pyrolysis variables, their influence on fiber characteristics, and the reuse of recycled fiber for a new composite were highlighted in this paper.

Industrial uses employing recycled fibers or resin, according to Oliveux et al., are uncommon. The authors claimed that this was due to a lack of trust in the quality of recycled fibers, as well as the fact that each batch of recycled composites comes from a variety of manufacturers and typically contains various fiber grades. This makes it difficult to manage the length, length uniformity, surface quality, and source of fibers. However, this does not rule out the possibility of other uses for recycled fiber [25]. In the same way, the current study (based on the literature) concluded that there are currently no commercially viable products created from short, thin, and nonaligned recovered fibers obtained by pyrolysis. More study on the use of recovered fibers is needed. On the other hand, according to Naqvi et al. (2018), recycled fibers may be used in a variety of ways 
other than competing with virgin materials, such as accessing new markets or creating new materials. Pickering et al. came to the conclusion that a $\mathrm{rCF} / \mathrm{rGF}$ 's worth may be increased by utilizing its unique features. The course rGF composites, for example, can be utilized as a core material because of their greater permeability, which acts as a flow channel [46]. However, based on the literature researched, it is important to identify the material cost reductions that may be achieved by using $\mathrm{rCF}$. While $\mathrm{rCF}$ are indeed cheaper than virgin fibers, they are inherently different from them, which has restricted their entry into the market. Based on cost and performance, the task was to modify the material in such a way that virgin fiber could be replaced with recycled fiber. Similarly, Job et al. found that because of the reduction in the quality of $\mathrm{rCF} / \mathrm{rGF}$, these fibers could only compete with lower-value materials like aluminum or cheaper virgin material composites. Additionally, quantity is critical, as economically viable processes need high throughputs. Market development is required to utilize large quantities of $\mathrm{rCF} / \mathrm{rGF}$. This means that either the $\mathrm{rCF} /$ cost must decrease to allow the $\mathrm{rCF} / \mathrm{rGF}$ to penetrate new markets, or the $\mathrm{rCF} / \mathrm{rGF}$ must seek out higher-value end markets [6].

According to Liu et al., optimization strategies may be discovered at all stages of the composite recycling and remanufacturing process. However, given the potential for optimization, these applications are still uncommon. Meanwhile, the majority of the strategies used to adjust parameters are a design of experiments strategies [7]. This is consistent with what was stated in the research: that there are currently no commercially viable products created from recovered fibers and that more studies and experiments on the use of recovered fibers are needed. According to Krauklis et al., pyrolysis is presently the most prevalent technique for recycling FRCs in the industry. Thermal recycling allows $\mathrm{rCF}$ to be recovered while retaining much of their reinforcing potential, whereas rGF is severely destroyed [1]. Similarly, this study concluded that pyrolysis seemed to be a realistic and promising approach because it was efficient in recovery and produced high characteristic fibers. On the other hand, Gharde et al. stated that recycling procedures should be chosen based on the kinds of composite materials and their ability to be reused in future applications. Every recycling process has its own set of benefits and drawbacks [3].

Pyrolysis, like any other recycling process, has several drawbacks, the most problematic of which is the probability of char development on the resultant fiber surface. Due to the char, the mechanical characteristics of the recovered fibers can be substantially decreased. Chemical treatment and post-heating the fibers both help to reduce char formation, but only to a limited extent.

A successful commercial-scale pyrolysis program was implemented in Germany and the United Kingdom. As a result of recycled fibers and other products like gas and oil, which may be utilized as feedstocks, the process has had a green impact. It is difficult to avoid char development in rGFs. It is also difficult to maintain the full mechanical characteristics of both CF and GF. A further heat/chemical treatment is required to remove small resin contaminants from the recovered fibers.

Both the oxidizing (air) and thermal $\left(\mathrm{N}_{2}\right)$ atmospheres were important in determining surface properties. Surface defects were discovered in an oxidizing atmosphere, resulting in a decrease in TS and crystallite size. As a result, for the recycling process to be successful, a regulated and optimum temperature and residence duration in post-pyrolysis is advantageous.

It is critical to figure out how to save money on materials by employing recovered carbon fibers as structural reinforcement, as well as how to find large-scale high-value applications for recovered carbon fibers. Although recycled fibers are less expensive than virgin fibers, they are fundamentally different, and this distinction has hampered their introduction into the virgin fiber market. The aim has thus been to alter the material such that virgin fiber is replaced with recycled fiber, based on cost and performance.

Pyrolysis can result in fibers that are short and discontinuous in carbon fiber composite materials. The use of these fibers has several advantages; cost-effectiveness, lightness, 3dimensional complexity in the panels, and a secondary framework for airplane interiors. 
In comparison to virgin fibers, thermochemically transformed recycled fibers showed superior mechanical properties. Moreover, recycled carbon fiber products in automotive applications deliver lighter and stronger components at high volume manufacturing rates, while also allowing considerable cost savings. For components and panels with complex shapes, discontinuous and thin fibers tend to produce excellent characteristics and 3D, intricate, low-weight structures.

For recycling CFRC/GFRC, pyrolysis has been classified as the most feasible and sustainable method for conserving resources and providing efficient recycling. However, the current study may be used to generate a variety of research topics. The following perspectives can be used to plan and solve future improvements in pyrolysis for the recovery of $\mathrm{CF} / \mathrm{GF}$ :

1. In an appropriate experimental facility, how well does pyrolysis perform for mixed and polluted scrape? In the majority of the work in the literature, there has been no mention of an FBR or any other reactor capable of processing mixed and polluted wastes.

2. Determination of the optimal variables of pyrolysis and post-pyrolysis are necessary in order to better comprehend the impact of pyrolysis. For further enhancement of the quality of the recovered fibers, research on the optimum variables of pyrolysis is needed.

3. In the literature, there is a gap in the examination of financial and energy-based evaluation of pyrolysis. The data will show that recycled fibers are better for the environment than EOL landfilling. Mathematical modeling may be built to show how pyrolysis and post-pyrolysis processing changes-as well as other important parameters-affect the cost and environmental effect.

4. There are currently no commercially viable products created from short, thin, and nonaligned recovered fibers obtained by pyrolysis. More study on the use of recovered fibers is needed.

5. When pyrolyzing a recycled composite, there is no information on fiber grading and fractionation to remove short fibers and retain excellent purity and strength without losing part of the fiber.

6. How can the original fiber length and strength be preserved following pyrolysis? The longer the starting fiber, the longer the recovered fiber-although better understanding of the effects of thermal and oxidation treatment is needed to enhance product quality and lower costs.

7. The lack of sizing on recycled fiber surfaces is a key study topic. This might result in inadequate adhesion among the polymer and recovered fibers, resulting in poor mechanical characteristics. The mechanical characteristics of recycled fibers might be significantly improved by pyrolysis resizing.

8. Pyrolysis improved the mechanical characteristics of recovered fibers when contrasted with incineration, gasification, mechanical, and chemical techniques. On the other hand, an inappropriate set of pyrolysis conditions has a detrimental impact on these characteristics (such as poor heating rates and high residence time). This compromise will not be accepted if the recovered fibers are to be used in a high-grade composite application.

9. It is unclear what effect fiber reclamation has on the performance of composites when compared to virgin and recovered composites with similar structures.

\section{Conclusions and Future Research}

The primary objectives of this research were to identify alternative pyrolysis recycling processes for CFRC and GFRC waste and prioritize the most sustainable techniques, with respect to financial and environmental considerations. Presently, the fate of waste CFRC and GFRC is mainly to be landfilled or incinerated, as these are the methods used by traditional waste disposal companies. However, many waste disposal businesses have switched to total fiber recovery technologies, considering concerns like sustainable 
alternates, circular economies, and climate change. This shift is taking place because of the significant contributions of researchers concentrating on the recycling of CFRC and GFRC waste. This review article briefly discusses these studies, and the results are summarized below:

1. Mechanical separation, incineration, gasification, and slower pyrolysis in a kiln are costly or yield low characteristic fibers. Pyrolysis may be a realistic and promising approach, because it is efficient in recovery and produces high characteristic fibers. The essential pyrolysis variables, their influence on fiber characteristics, and the re-use of recycled fibers for new composites were highlighted in this paper.

2. A successful commercial-scale pyrolysis program was implemented in Germany and the United Kingdom, and they have the ability to recycle CFRC in various forms. They may also recover longer and cleaner $\mathrm{CFs}$, thanks to the big furnace and continuous flow.

3. Pyrolysis, like any other recycling process, has several drawbacks, the most problematic of which is the probability of char development on the resultant fiber surface. Due to char, the mechanical characteristics of the recovered fibers will be substantially decreased. Chemical treatment and post-heating of the fibers both help to reduce char formation, but only to a limited extent.

4. Pyrolysis in a nitrogen gas environment, unlike vacuum pyrolysis, may recycle both CFRC and GFRC.

5. In pyrolysis, using a superheated steam atmosphere improves heat transmission, which accelerates the thermal breakdown and supports eliminating oxygen from the reactor. In comparison to other pyrolysis atmospheres, recycling CFRC with superheated steam leads to high retention of CF mechanical characteristics.

6. According to the study, the higher the value of recycled $\mathrm{CF}$, the lower the pyrolysis temperature.

7. Microwave pyrolysis has enhanced the rate of heat while consuming a smaller quantity of energy, without interfering with the basic principle of pyrolysis. The method may recycle both CFRC and GFRC fibers while preserving greater mechanical characteristics.

8. Both the oxidizing (air) and thermal $\left(\mathrm{N}_{2}\right)$ atmospheres were important in determining surface properties. Surface defects were discovered in an oxidizing atmosphere, resulting in a decrease in TS and crystallite size. As a result, for a successful recycling process, a regulated and optimum temperature and residence duration in post-pyrolysis is advantageous.

9. Recycling CFRC/GFRC by pyrolysis has great potential, since it recovers precious fibers and produces gas and liquid products.

10. According to published research, the breakdown temperature of resin is complete between $450-500{ }^{\circ} \mathrm{C}$ in the case of GRFC. Meanwhile, CFRC breakdown temperatures are between $450-600{ }^{\circ} \mathrm{C}$, depending on kind and whether it is cured or uncured. For post-pyrolysis in the air atmosphere, $500-600{ }^{\circ} \mathrm{C}$ was found to be the optimal temperature for oxidizing char and cleaning the fiber surface.

11. It is important to identify the material cost reductions that may be achieved by using rCF. While rCF are cheaper than virgin fibers, they are inherently different from them, which has restricted the entry of $\mathrm{rCF}$ into the vCF market. Based on cost and performance, the task will be to modify the material in such a way that virgin fiber is replaced with recycled fiber.

12. In the case of carbon fiber composite materials, pyrolysis can result in fibers that are short in length and discontinuous. There are certain advantages to using these fibers, such as: cost-effectiveness, light weight, a 3-dimensional complexity in the panels, and a secondary structure for airplane interiors. Thermochemically converted recycled fibers demonstrate good mechanical characteristics compared to virgin fibers.

13. Recycled carbon fiber products in automobile applications deliver lighter and stronger components at high volume manufacturing rates, as well as considerable cost sav- 
ings. Nonaligned and short fibers tend to generate excellent quality, 3D complicated, lightweight constructions for components and panels with complex forms.

The following identified research gaps and future prospects might be investigated or created and resolved for further developments of this technique to recover fibers:

1. How effective/feasible is pyrolysis for mixed and polluted composite wastes?

2. It is necessary to gain a better understanding of the influence of operational factors (heating temperature, reaction time, chemical solvent) on CF/GF. Further research into the optimum parameters is necessary to improve the quality of CF/GF.

3. The impact of fiber recovery on composite quality (in comparison to $\mathrm{vCF} / \mathrm{vGF}$ and remanufactured composites with $\mathrm{rCF} / \mathrm{rGF}$ using the same structures) is unclear.

4. How can $\mathrm{rCF} / \mathrm{rGF}$ strength and length be compared to $\mathrm{vCF} / \mathrm{vGF}$ using this method? Additional performance improvements will need a better understanding of pyrolysis interactions with chemical treatment.

5. How could the total costs of the recycling and remanufacturing of composites be lowered so that pyrolysis may be used as a recycling technique on a large scale?

6. The use of $\mathrm{rCF} / \mathrm{rGF}$ after recovery from pyrolysis is a current field of study; such studies may play a major role in enhancing the characteristics of the products generated from them.

7. Crosslinking of fibers also limits reusing of $\mathrm{rCF} / \mathrm{rGF}$ in new composites. If RFs are re-aligned in the same way as $\mathrm{VCF} / \mathrm{vGF}$, their potential uses could be improved.

8. Chemical treatment plays a role in improving the mechanical and physical characteristics of $\mathrm{rCF} / \mathrm{rGF}$. This involves research into the reaction of functional groups to resin interactions. Chemical treatment at the connection between these functional groups and the resin matrix may also be involved.

Author Contributions: R.A., A.J. and, F.M.-A. conceived of the idea and wrote the article; M.A.S. and A.J. analyzed the paper; R.A., H.Ç., and M.A.S. wrote the paper. A.A., S.A. and F.M.-A. supervised the research and revised the manuscript. All authors contributed to the structure and aims of the manuscript, paper drafting, editing, and review. All authors have read and approved the final manuscript.

Funding: This research has been supported by the Ministry of Science, Innovation, and Universities at the University of Almeria (Spain) under the program "Proyectos d e I+D de Generación de Conocimiento" of the national program for the generation of scientific and technological knowledge and strengthening of the R+D+I system, with grant number PGC2018-098813-B-C33.

Institutional Review Board Statement: Not applicable.

Informed Consent Statement: Not applicable.

Data Availability Statement: This study did not report any data.

Acknowledgments: The authors would like to acknowledge the An Najah National University, Near East University-Nicosia; German Jordanian University and University of Almeria for facilitating this research.

Conflicts of Interest: The authors declare no conflict of interest.

\section{Abbreviations}

ACMs Advanced Composite Materials

Al Aluminum

ATR Attenuated total reflection

CF Carbon fiber

CFRC Carbon fiber-reinforced composite

CFRP Carbon-fiber reinforced polymer

DTG Differential thermogravimetry

E Young modulus 


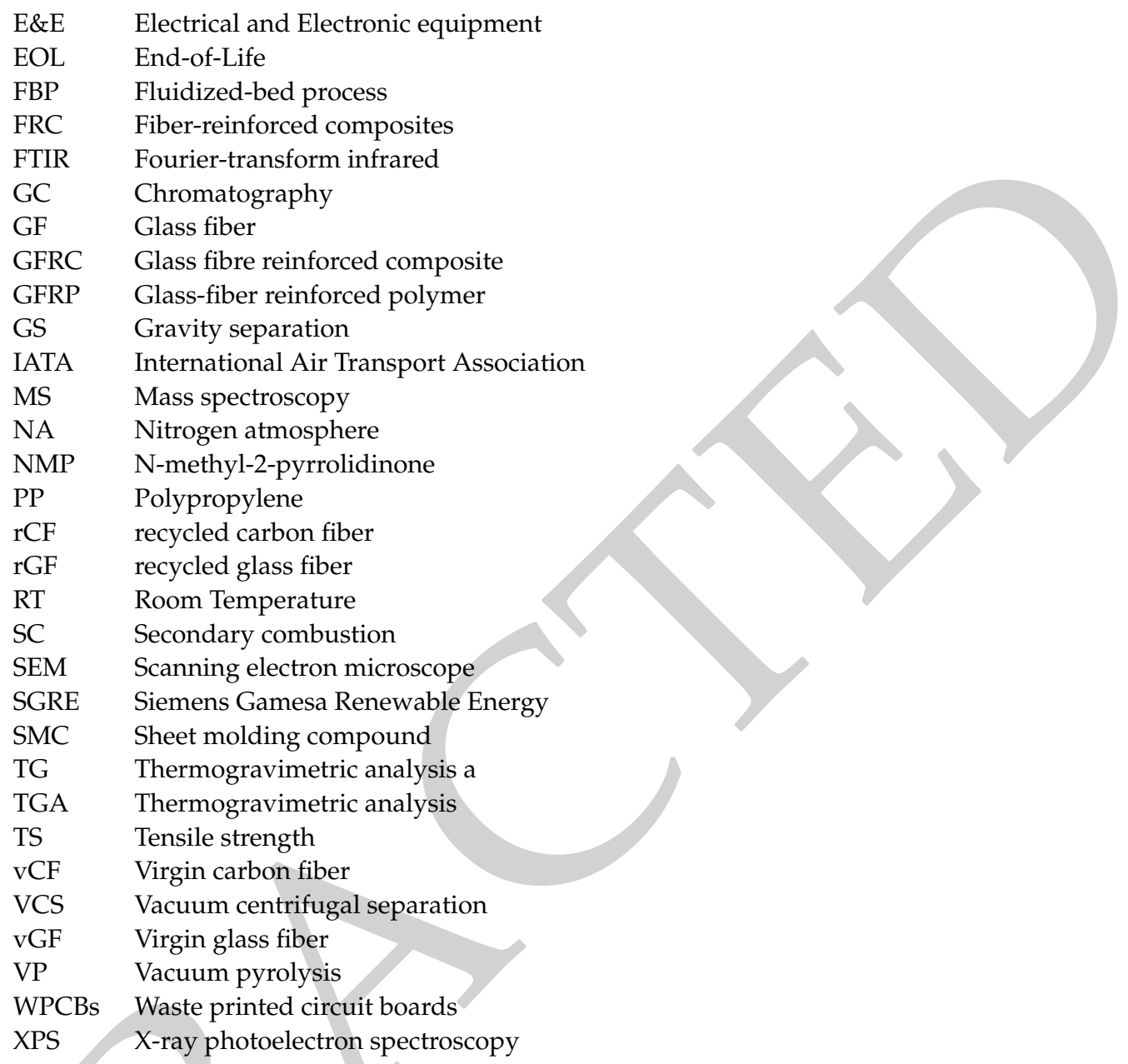

\section{References}

1. Krauklis, A.E.; Karl, C.W.; Gagani, A.I.; Jørgensen, J.K. Composite Material Recycling Technology-State-of-the-Art and Sustainable Development for the 2020s. J. Compos. Sci. 2021, 5, 28. [CrossRef]

2. Amaechi, C.V.; Odijie, A.C.; Orok, E.O.; Ye, J. Economic aspects of fiber reinforced polymer composite recycling. Encycl. Renew. Sustain. Mater. 2020, 2, 377-397. [CrossRef]

3. Gharde, S.; Kandasubramanian, B. Mechanothermal and chemical recycling methodologies for the Fibre Reinforced Plastic (FRP). Environ. Technol. Innov. 2019, 14, 100311. [CrossRef]

4. WindEurope-Cefic-EuCIA. Accelerating Wind Turbine Blade Circularity. White Paper. 2020. Available online: https: //windeurope.org/wp-content/uploads/files/about-wind/reports/WindEurope-Accelerating-wind-turbine-bladecircularity. pdf (accessed on 11 August 2021).

5. The International Air Transport Association (IATA). Helping Aircraft Decommissioning. 2020. Available online: https://www. iata.org/en/programs/environment/aircraft-decommissioning/ (accessed on 11 August 2021).

6. Job, S. Recycling composites commercially. Reinf. Plast. 2014, 58, 32-38. [CrossRef]

7. Liu, Y.; Farnsworth, M.; Tiwari, A. A review of optimisation techniques used in the composite recycling area: State-of-the-art and steps towards a research agenda. J. Clean. Prod. 2017, 140, 1775-1781. [CrossRef]

8. Global Wind Energy Council. Global Wind Report. 2021. Available online: https://gwec.net/global-wind-report-2021/ (accessed on 20 August 2021).

9. Holmes, M. Recycled carbon fiber composites become a reality. Reinf. Plast. 2018, 62, 148-153. [CrossRef]

10. Yang, Y.; Boom, R.; Irion, B.; van Heerden, D.J.; Kuiper, P.; de Wit, H. Recycling of composite materials. Chem. Eng. Process. Process. Intensif. 2012, 51, 53-68. [CrossRef]

11. Chen, T.; Kazerooni, D.; Ju, L.; Okonski, D.A.; Baird, D.G. Development of Recyclable and High-Performance In Situ Hybrid TLCP/Glass Fiber Composites. J. Compos. Sci. 2020, 4, 125. [CrossRef]

12. Amaechi, C.V.; Agbomerie, C.O.; Sotayo, A.; Wang, F.; Hou, X.; Ye, J. Recycling of Renewable Composite Materials in the Offshore Industry. In Reference Module in Materials Science and Materials Engineering; Elsevier: Amsterdam, The Netherlands, 2019. [CrossRef] 
13. Gagani, A.I.; Krauklis, A.E.; Echtermeyer, A.T. Orthotropic fluid diffusion in composite marine structures. Experimental procedure, analytical and numerical modelling of plates, rods and pipes. Compos. Part A Appl. Sci. Manuf. 2018, 115, 196-205. [CrossRef]

14. Rocha, I.B.C.M.; Parente, E., Jr.; Melo, A.M.C. A hybrid shared/distributed memory parallel genetic algorithm for optimization of laminate composites. Compos. Struct. 2014, 107, 288-297. [CrossRef]

15. Gagani, A.; Krauklis, A.; Echtermeyer, A.T. Anisotropic fluid diffusion in carbon fiber reinforced composite rods: Experimental, analytical and numerical study. Mar. Struct. 2018, 59, 47-59. [CrossRef]

16. Starkova, O.; Aniskevich, A. Modelling of moisture sorption by CFRP rebars with vinylester matrix. Adv. Compos. Lett. 2004, 13, 096369350401300603. [CrossRef]

17. Gagani, A.I.; Krauklis, A.E.; Sæter, E.; Vedvik, N.P.; Echtermeyer, A.T. A novel method for testing and determining ILSS for marine and offshore composites. Compos. Struct. 2019, 220, 431-440. [CrossRef]

18. Rubino, F.; Nisticò, A.; Tucci, F.; Carlone, P. Marine application of fiber reinforced composites; A review. J. Mar. Sci. Eng. 2020, 8, 26. [CrossRef]

19. Jayalakshmi, C.G.; Inamdar, A.; Anand, A.; Kandasubramanian, B. Polymer matrix composites as broadband radar absorbing structures for stealth aircrafts. J. Appl. Polym. Sci. 2019, 136, 47241. [CrossRef]

20. Marsh, G. What's to be done with 'spent'wind turbine blades? Renew. Energy Focus 2017, 22, 20-23. [CrossRef]

21. Belton, P. What Happens to All the Old Wind Turbines? BBC News: Business. 22 February 2020. Available online: https: //www.bbc.com/news/business-51325101 (accessed on 11 May 2021).

22. Liu, P.; Barlow, C.Y. Wind turbine blade waste in 2050. Waste Manag. 2017, 62, 229-240. [CrossRef]

23. Rescalvo, F.J.; Valverde-Palacios, I.; Suarez, E.; Roldán, A.; Gallego, A. Monitoring of carbon fiber-reinforced old timber beams via strain and multi resonant acoustic emission sensors. Sensors 2018, 18, 1224. [CrossRef] [PubMed]

24. Asmatulu, E.; Twomey, J.; Overcash, M. Recycling of fiber reinforced composites and direct structural composite recycling concept. J. Compos. Mater. 2014, 48, 593-608. [CrossRef]

25. Oliveux, G.; Dandy, L.O.; Leeke, G.A. Current status of recycling of fibre reinforced polymers: Review of technologies, reuse and resulting properties. Prog. Mater. Sci. 2015, 72, 61-99. [CrossRef]

26. Jensen, J.P.; Skelton, K. Wind turbine blade recycling: Experiences, challenges, and possibilities in a circular economy. Renew Sustain. Energy Rev. 2018, 97, 165-176. [CrossRef]

27. Lefeuvre, A.; Garnier, S.; Jacquemin, L.; Pillain, B.; Sonnemann, G. Anticipating in-use stocks of carbon fiber reinforced polymers and related waste flows generated by the commercial aeronautical sector until 2050. Resour. Conserv. Recycl. 2017, 125, 264-272 [CrossRef]

28. Erden, S.; Ho, K. Fiber-reinforced composites. In Fiber Technology for Fiber-Reinforced Composites; Woodhead Publishing: John Solston, UK, 2017; pp. 51-79.

29. Pimenta, S.; Pinho, S.T. Recycling carbon fiber reinforced polymers for structural applications: Technology review and market outlook. Waste Manag. 2011, 31, 378-392. [CrossRef] [PubMed]

30. Cousins, D.S.; Suzuki, Y.; Murray, R.E.; Samaniuk, J.R.; Stebner, A.P. Recycling glass fiber thermoplastic composites from wind turbine blades. J. Clean. Prod. 2019, 209, 1252-1263. [CrossRef]

31. Yao, S.; Jin, F.; Rhee, K.Y.; Hui, D.; Park, S. Recent advances in carbon fiber-reinforced thermoplastic composites: A review. Compos. B Eng. 2018, 142, 241-250. [CrossRef]

32. Bachmann, J.; Hidalgo, C.; Bricout, S. Environmental analysis of innovative sustainable composites with potential use in aviation sector-A life cycle assessment review. Sci. China Technol. Sci. 2017, 60, 1301-1317. [CrossRef]

33. Hadi, P.; Ning, C.; Ouyang, W.; Xu, M.; Lin, C.S.; McKay, G. Toward environmentally benign utilization of nonmetallic fraction of waste printed circuit boards as modifier and precursor. Waste Manag. 2015, 35, 236-246. [CrossRef] [PubMed]

34. Liu, P.; Meng, F.; Barlow, C.Y. Wind turbine blade end-of-life options: An eco-audit comparison. J. Clean. Prod. 2019, 212, 1268-1281. [CrossRef]

35. Pillain, B.; Loubet, P.; Pestalozzi, F.; Woidasky, J.; Erriguible, A.; Aymonier, C.; Sonnemann, G. Positioning supercritical solvolysis among innovative recycling and current waste management scenarios for carbon fiber reinforced plastics thanks to comparative life cycle assessment. J. Supercrit. Fluids 2019, 154, 104607. [CrossRef]

36. Li, X.; Bai, R.; McKechnie, J. Environmental and financial performance of mechanical recycling of carbon fibre reinforced polymers and comparison with conventional disposal routes. J. Clean. Prod. 2016, 127, 451-460. [CrossRef]

37. Prinçaud, M.; Aymonier, C.; Loppinet-Serani, A.; Perry, N.; Sonnemann, G. Environmental feasibility of the recycling of carbon fibers from CFRPs by solvolysis using supercritical water. ACS Sustain. Chem. Eng. 2014, 2, 1498-1502. [CrossRef]

38. Nunes, A.O.; Viana, L.R.; Guineheuc, P.M.; da Silva Moris, V.A.; de Paiva JM, F.; Barna, R.; Soudais, Y. Life cycle assessment of a steam thermolysis process to recover carbon fibers from carbon fiber-reinforced polymer waste. Int. J. Life Cycle Assess 2017, 23, 1825-1838. [CrossRef]

39. Witik, R.A.; Teuscher, R.; Michaud, V.; Ludwig, C.; Månson, J.A.E. Carbon fibre reinforced composite waste: An environmental assessment of recycling, energy recovery and landfilling. Compos. Part A Appl. Sci. Manuf. 2013, 49, 89-99. [CrossRef]

40. Naqvi, S.R.; Prabhakara, H.M.; Bramer, E.A.; Dierkes, W.; Akkerman, R.; Brem, G. A critical review on recycling of end-of-life carbon fibre/glass fibre reinforced composites waste using pyrolysis towards a circular economy. Resour. Conserv. Recycl. 2018, 136, 118-129. [CrossRef] 
41. Meng, F.; Olivetti, E.A.; Zhao, Y.; Chang, J.C.; Pickering, S.J.; McKechnie, J. Comparing life cycle energy and global warming potential of carbon fiber composite recycling technologies and waste management options. ACS Sustain. Chem. Eng. 2018, 6, 9854-9865. [CrossRef]

42. Moriyama, A.; Hasegawa, T.; Nagaya, C.; Hamada, K.; Himaki, T.; Murakami, M.; Horie, M.; Takahashi, J.; Iwahashi, H.; Moritomi, H. Assessment of harmfulness and biological effect of carbon fiber dust generated during new carbon fiber recycling method. J. Hazard. Mater. 2019, 378, 120777. [CrossRef] [PubMed]

43. Roberts, T. Rapid growth forecast for carbon fiber market. Reinf. Plast. 2007, 51, 10-13. [CrossRef]

44. Rybicka, J.; Tiwari, A.; Leeke, G.A. Technology readiness level assessment of composites recycling technologies. J. Clean. Prod. 2016, 112, 1001-1012. [CrossRef]

45. Rodrigues, G.G.M.; de Paiva, J.M.F.; do Carmo, J.B.; Botaro, V.R. Recycling of carbon fibers inserted in composite of DGEBA epoxy matrix by thermal degradation. Polym. Degrad. Stab. 2014, 109, 50-58. [CrossRef]

46. Pickering, S.J. Recycling technologies for thermoset composite materials-Current status. Compos. Part A Appl. Sci. Manuf. 2006, 37, 1206-1215. [CrossRef]

47. Vo Dong, P.A.; Azzaro-Pantel, C.; Cadene, A.-L. Economic and environmental assessment of recovery and disposal pathways for CFRP waste management. Resour. Conserv. Recycl. 2018, 133, 63-75. [CrossRef]

48. Thomason, J.L.; Nagel, U.; Yang, L.; Sáez, E. Regenerating the strength of thermally recycled glass fibres using hot sodium hydroxide. Compos. Part A Appl. Sci. Manuf. 2016, 87, 220-227. [CrossRef]

49. Yang, L.; Sáez, E.R.; Nagel, U.; Thomason, J.L. Can thermally degraded glass fibre be regenerated for closed-loop recycling of thermosetting composites? Compos. Part A Appl. Sci. Manuf. 2015, 72, 167-174. [CrossRef]

50. Nagel, U.; Yang, L.; Kao, C.C.; Thomason, J.L. Effects of thermal recycling temperatures on the reinforcement potential of glass fibers. Polym. Compos. 2018, 39, 1032-1040. [CrossRef]

51. Pender, K.; Yang, L. Investigation of the potential for catalysed thermal recycling in glass fiber reinforced polymer composites by using metal oxides. Compos. A Appl. Sci. Manuf. 2017, 100, 285-293. [CrossRef]

52. Pickering, S.J.; Kelly, R.M.; Kennerley, J.R.; Rudd, C.D.; Fenwick, N.J. A fluidised-bed process for the recovery of glass fibres from scrap thermoset composites. Compos. Sci. Technol. 2000, 60, 509-523. [CrossRef]

53. Zheng, Y.; Shen, Z.; Ma, S.; Cai, C.; Zhao, X.; Xing, Y. A novel approach to recycling of glass fibers from nonmetal materials of waste printed circuit boards. J. Hazard. Mater. 2009, 170, 978-982. [CrossRef] [PubMed]

54. Pender, K.; Yang, L. Investigation of catalyzed thermal recycling for glass fber-reinforced epoxy using fuidized bed process. Polym. Compos. 2019, 40, 3510-3519. [CrossRef]

55. Yip, H.L.H.; Pickering, S.J.; Rudd, C.D. Characterisation of carbon fibres recycled from scrap composites using fluidised bed process. Plast. Rubber. Compos. 2002, 31, 278-282. [CrossRef]

56. Pickering, S.J.; Turner, T.A.; Meng, F.; Morris, C.N.; Heil, J.P.; Wong, K.H.; Melendi-Espina, S. Developments in the Fluidised Bed Process for Fibre Recovery from Thermoset Composites. In Proceedings of the 2nd Annual Composites and Advanced Materials Expo, CAMX 2015, Dallas, TX, USA, 26-26 October 2015; pp. 2384-2394.

57. Ribeiro, M.C.S.; Meira-Castro, A.C.; Silva, F.G.; Santos, J.; Meixedo, J.P.; Fiúza, A.; Dinis, M.L.; Alvim, M.R. Re-use assessment of thermoset composite wastes as aggregate and filler replacement for concrete-polymer composite materials: A case study regarding GFRP pultrusion wastes. Resour. Conserv. Recycl. 2015, 104, 417-426. [CrossRef]

58. Wong, K.; Rudd, C.; Pickering, S.; Liu, X. Composites recycling solutions for the aviation industry. Sci. China Technol. Sci. 2017, 60, 1291-1300. [CrossRef]

59. Gopalraj, S.K.; Kärki, T. A review on the recycling of waste carbon fibre/glass fibre-reinforced composites: Fibre recovery, properties and life-cycle analysis. SN Appl. Sci. 2020, 2, 1-21.

60. Meyer, L.O.; Schulte, K.; Grove-Nielsen, E. CFRP-recycling following a pyrolysis route: Process optimization and potentials. J. Compos. Mater. 2009, 43, 1121-1132. [CrossRef]

61. Giorgini, L.; Benelli, T.; Mazzocchetti, L.; Leonardi, C.; Zattini, G.; Minak, G.; Dolcini, E.; Tosi, C.; Montanari, I. Pyrolysis as a way to close a CFRC life cycle: Carbon fibers recovery and their use as feedstock for a new composite production. In AIP Conference Proceedings; American Institute of Physics: College Park, MD, USA, 2014; Volume 1599, pp. 354-357.

62. Onwudili, J.A.; Miskolczi, N.; Nagy, T.; Lipóczi, G. Recovery of glass fibre and carbon fibres from reinforced thermosets by batch pyrolysis and investigation of fibre re-using as reinforcement in LDPE matrix. Compos. Part B Eng. 2016, 91, 154-161. [CrossRef]

63. Louwes, A.C.; Basile, L.; Yukananto, R.; Bhagwandas, J.C.; Bramer, E.A.; Brem, G. Torrefied biomass as feed for fast pyrolysis: An experimental study and chain analysis. Biomass Bioenergy 2017, 105, 116-126. [CrossRef]

64. Abdou, T.R.; Espinosa, D.C.R.; Tenório, J.A.S. Recovering of carbon fiber present in an industrial polymeric composite waste through pyrolysis method while studying the influence of resin impregnation process: Prepreg. In Towards Materials Resource Sustainability; Kirchain, R.E., Blanpain, B., Meskers, C., Eds.; REWAS 2016; Springer International Publishing: Berlin/Heidelberg, Germany, 2016; pp. 313-318.

65. Habib Al Razi, K.M. Resourceful recycling process of waste desktop computers: A review study. Resour. Conserv. Recycl. 2016, 110, 30-47. [CrossRef]

66. Poulikakos, L.D.; Papadaskalopoulou, C.; Hofko, B.; Gschösser, F.; Falchetto, A.C.; Bueno, M.; Arraigada, M.; Sousa, J.; Ruiz, R.; Petit, C.; et al. Harvesting the unexplored potential of European waste materials for road construction. Resour. Conserv. Recycl. 2017, 116, 32-44. [CrossRef] 
67. Shen, Y. Effect of chemical pretreatment on pyrolysis of non-metallic fraction recycled from waste printed circuit boards. Waste Manag. 2018, 76, 537-543. [CrossRef]

68. Shi, J.; Bao, L.; Kobayashi, R.; Kato, J.; Kemmochi, K. Reusing recycled fibers in high-value fiber-reinforced polymer composites: Improving bending strength by surface cleaning. Compos. Sci. Technol. 2012, 72, 1298-1303. [CrossRef]

69. Limburg, M.; Stockschläder, J.; Quicker, P. Thermal treatment of carbon fibre reinforced polymers (Part 1: Recycling). Waste Manag. Res. 2019, 37, 73-82. [CrossRef]

70. Mazzocchetti, L.; Benelli, T.; D'Angelo, E.; Leonardi, C.; Zattini, G.; Giorgini, L. Validation of carbon fibers recycling by pyrogasification: The influence of oxidation conditions to obtain clean fibers and promote fiber/matrix adhesion in epoxy composites. Compos. Part A Appl. Sci. Manuf. 2018, 112, 504-514. [CrossRef]

71. Zhou, Y.; Qiu, K. A new technology for recycling materials from waste printed circuit boards. J. Hazard. Mater. 2010, 175, 823-828. [CrossRef] [PubMed]

72. Zhou, Y.; Wu, W.; Qiu, K. Recovery of materials from waste printed circuit boards by vacuum pyrolysis and vacuum centrifugal separation. Waste Manag. 2010, 30, 2299-2304. [CrossRef] [PubMed]

73. Long, L.; Sun, S.; Zhong, S.; Dai, W.; Liu, J.; Song, W. Using vacuum pyrolysis and mechanical processing for recycling waste printed circuit boards. J. Hazard. Mater. 2010, 177, 626-632. [CrossRef]

74. Onwudili, J.A.; Insura, N.; Williams, P.T. Autoclave pyrolysis of carbon reinforced composite plastic waste for carbon fibre and chemicals recovery. J. Energy Inst. 2013, 86, 227-232. [CrossRef]

75. Shi, J.; Wada, S.; Kemmochi, K.; Bao, L. Development of recycling system for fiber-reinforced plastics by superheated steam. In Key Engineering Materials; Trans Tech Publications: Zurich, Switzerland, 2011; Volume 464, pp. 414-418. [CrossRef]

76. Shi, J.; Kemmochi, K.; Bao, L.M. Research in recycling technology of fiber reinforced polymers for reduction of environmental load: Optimum decomposition conditions of carbon fiber reinforced polymers in the purpose of fiber reuse. In Advanced Materials Research; Trans Tech Publications Ltd.: Zurich, Switzerland, 2012; Volume 343, pp. 142-149.

77. Kim, K.W.; Lee, H.M.; An, J.H.; Chung, D.C.; An, K.H.; Kim, B.J. Recycling and characterization of carbon fibers from carbon fiber reinforced epoxy matrix composites by a novel super-heated-steam method. J. Environ. Manag. 2017, 203, 872-879. [CrossRef]

78. Jeong, J.S.; Kim, K.W.; An, K.H.; Kim, B.J. Fast recovery process of carbon fibers from waste carbon fibers-reinforced thermoset plastics. J. Environ. Manag. 2019, 247, 816-821. [CrossRef]

79. Ye, S.Y.; Bounaceur, A.; Soudais, Y.; Barna, R. Parameter optimization of the steam thermolysis: A process to recover carbon fibers from polymer-matrix composites. Waste Biomass Valorization 2013, 4, 73-86. [CrossRef]

80. Kim, K.W.; Jeong, J.S.; An, K.H.; Kim, B.J. A low energy recycling technique of carbon fibers-reinforced epoxy matrix composites. Ind. Eng. Chem. Res. 2018, 58, 618-624. [CrossRef]

81. Obunai, K.; Fukuta, T.; Ozaki, K. Carbon fber extraction from waste CFRP by microwave irradiation. Compos. A Appl. Sci. Manuf. 2015, 78, 160-165. [CrossRef]

82. Jiang, L.; Ulven, C.A.; Gutschmidt, D.; Anderson, M.; Balo, S.; Lee, M.; Vigness, J. Recycling carbon fiber composites using microwave irradiation: Reinforcement study of the recycled fiber in new composites. J. Appl. Polym. Sci. 2015, 132. Available online: https:/ / onlinelibrary.wiley.com/doi/epdf/10.1002/app.42658 (accessed on 9 September 2021). [CrossRef]

83. Beauson, J.; Lilholt, H.; Brøndsted, P. Recycling solid residues recovered from glass fibre-reinforced composites-A review applied to wind turbine blade materials. J. Reinf. Plast. Compos. 2014, 33, 1542-1556. [CrossRef]

84. Pico, D.; Seide, G.; Gries, T. Thermo chemical processes: Potential improvement of the wind blades life cycle. Chem. Eng. Trans. 2014, 36, 211-216.

85. Åkesson, D.; Krishnamoorthi, R.; Foltynowicz, Z.; Christéen, J.; Kalantar, A.; Skrifvars, M. Glass fibres recovered by microwave pyrolysis as a reinforcement for polypropylene. Polym. Polym. Compos. 2013, 21, 333-340. [CrossRef]

86. Åkesson, D.; Foltynowicz, Z.; Christeen, J.; Skrifvars, M. Microwave pyrolysis as a method of recycling glass fibre from used blades of wind turbines. J. Reinf. Plast. Compos. 2012, 31, 1136-1142. [CrossRef]

87. Åkesson, D.; Foltynowicz, Z.; Christéen, J.; Skrifvars, M. Products obtained from decomposition of glass fber-reinforced composites using microwave pyrolysis. Polimery 2013, 58, 582-586. [CrossRef]

88. Jiang, G.; Pickering, S.J.; Walker, G.S.; Wong, K.H.; Rudd, C.D. Surface characterisation of carbon fibre recycled using fluidised bed. Appl. Surf. Sci. 2008, 254, 2588-2593. [CrossRef]

89. Jiang, G.; Pickering, S.J. Structure-property relationship of recycled carbon fibres revealed by pyrolysis recycling process. J. Mater. Sci. 2016, 51, 1949-1958. [CrossRef]

90. Bücheler, D.; Kaiser, A.; Henning, F. Using thermogravimetric analysis to determine carbon fiber weight percentage of fiberreinforced plastics. Compos. Part B Eng. 2016, 106, 218-223. [CrossRef]

91. Yun, Y.M.; Seo, M.W.; Koo, G.H.; Ra, H.W.; Yoon, S.J.; Kim, Y.K.; Lee, J.G.; Kim, J.H. Pyrolysis characteristics of GFRP (Glass Fiber Reinforced Plastic) under non-isothermal conditions. Fuel 2014, 137, 321-327. [CrossRef]

92. Giorgini, L.; Leonardi, C.; Mazzocchetti, L.; Zattini, G.; Cavazzoni, M.; Montanari, I.; Tosi, C.; Benelli, T. Pyrolysis of fiberglass/polyester composites: Recovery and characterization of obtained products. FME Trans. 2016, 44, 405-414. [CrossRef]

93. Giorgini, L.; Benelli, T.; Mazzocchetti, L.; Leonardi, C.; Zattini, G.; Minak, G.; Dolcini, E.; Cavazzoni, M.; Montanari, I.; Tosi, C. Recovery of carbon fibers from cured and uncured carbon fiber reinforced composites wastes and their use as feedstock for a new composite production. Polym. Compos. 2015, 36, 1084-1095. [CrossRef] 
94. Das, M.; Varughese, S. A novel sonochemical approach for enhanced recovery of carbon fiber from CFRP waste using mild acid-peroxide mixture. ACS Sustain. Chem. Eng. 2016, 4, 2080-2087.

95. Yildirir, E.; Miskolczi, N.; Onwudili, J.A.; Németh, K.E.; Williams, P.T.; Sója, J. Evaluating the mechanical properties of reinforced LDPE composites made with carbon fibres recovered via solvothermal processing. Compos. Part B Eng. 2015, 78, 393-400. [CrossRef]

96. Song, C.; Wang, F.; Liu, Y.; Wang, X.; Yang, B. Recycling carbon fiber from composite waste and its reinforcing effect on polyvinylidene fluoride composite: Mechanical, morphology, and interface properties. Polym. Compos. 2017, 38, $2544-2552$. [CrossRef]

97. Longana, M.L.; Ong, N.; Yu, H.; Potter, K.D. Multiple closed loop recycling of carbon fibre composites with the HiPerDiF (High Performance Discontinuous Fibre) method. Compos. Struct. 2016, 153, 271-277. [CrossRef]

98. Bradna, P.; Zima, J. Compositional analysis of epoxy matrices of carbon-fibre composites by pyrolysis-gas chromatography/mass spectrometry. J. Anal. Appl. Pyrolysis 1992, 24, 75-85. [CrossRef]

99. Nahil, M.A.; Williams, P.T. Recycling of carbon fibre reinforced polymeric waste for the production of activated carbon fibres. J. Anal. Appl. Pyrolysis 2011, 91, 67-75. [CrossRef]

100. Greco, A.; Maffezzoli, A.; Buccoliero, G.; Caretto, F.; Cornacchia, G. Thermal and chemical treatments of recycled carbon fibres for improved adhesion to polymeric matrix. J. Compos. Mater. 2013, 47, 369-377. [CrossRef]

101. Cunliffe, A.M.; Jones, N.; Williams, P.T. Recycling of fibre-reinforced polymeric waste by pyrolysis: Thermo-gravimetric and bench-scale investigations. J. Anal. Appl. Pyrolysis 2003, 70, 315-338. [CrossRef]

102. Cunliffe, A.M.; Williams, P.T. Characterisation of products from the recycling of glass fibre reinforced polyester waste by pyrolysis 放. Fuel 2003, 82, 2223-2230. [CrossRef]

103. Stoeffler, K.; Andjelic, S.; Legros, N.; Roberge, J.; Schougaard, S.B. Polyphenylene sulfide (PPS) composites reinforced with recycled carbon fiber. Compos. Sci. Technol. 2013, 84, 65-71. [CrossRef]

104. Torres, A.; De Marco, I.; Caballero, B.M.; Laresgoiti, M.F.; Legarreta, J.A.; Cabrero, M.A.; Gonzalez, A.; Chomon, M.J.; Gondra, K. Recycling by pyrolysis of thermoset composites: Characteristics of the liquid and gaseous fuels obtained. Fuel 2000, 79, 897-902. [CrossRef]

105. Torres, A.; De Marco, I.; Caballero, B.M.; Laresgoiti, M.F.; Chomón, M.J.; Kondra, G. Recycling of the solid residue obtained from the pyrolysis of fiberglass polyester sheet molding compound. Adv. Polym. Technol. J. Polym. Process. Inst. 2009, 28, 141-149. [CrossRef]

106. López, F.A.; Rodríguez, O.; Alguacil, F.J.; García-Díaz, I.; Centeno, T.A.; García-Fierro, J.L.; González, C. Recovery of carbon fibres by the thermolysis and gasification of waste prepreg. J. Anal. Appl. Pyrolysis 2013, 104, 675-683. [CrossRef]

107. López, F.A.; Martín, M.I.; Alguacil, F.J.; Rincón, J.M.; Centeno, T.A.; Romero, M. Thermolysis of fibreglass polyester composite and reutilisation of the glass fibre residue to obtain a glass-ceramic material. J. Anal. Appl. Pyrolysis 2012, 93, 104-112. [CrossRef]

108. Yun, Y.M.; Seo, M.W.; Ra, H.W.; Koo, G.H.; Oh, J.S.; Yoon, S.J.; Kim, Y.K.; Lee, J.G.; Kim, J.H. Pyrolysis characteristics of glass fiber-reinforced plastic (GFRP) under isothermal conditions. J. Anal. Appl. Pyrolysis 2015, 114, 40-46. [CrossRef]

109. Overcash, M.; Twomey, J.; Asmatulu, E.; Vozzola, E.; Griffing, E. Thermoset composite recycling-Driving forces, development, and evolution of new opportunities. J. Compos. Mater. 2018, 52, 1033-1043. [CrossRef]

110. Pinho, S.; Ferreira, M.; Almeida, M.F. A wet dismantling process for the recycling of computer printed circuit boards. Resour. Conserv. Recycl. 2018, 132, 71-76. [CrossRef]

111. Liu, K.; Zhang, Z.; Zhang, F.-S. Advanced degradation of brominated epoxy resin and simultaneous transformation of glass fiber from waste printed circuit boards by improved supercritical water oxidation processes. Waste Manag. 2016, 56, 423-430. [CrossRef]

112. Meng, F.; McKechnie, J.; Pickering, S.J. An assessment of financial viability of recycled carbon fibre in automotive applications. Compos. Part A Appl. Sci. Manuf. 2018, 109, 207-220. [CrossRef]

113. Gebisa, A.W.; Lemu, H.G. A case study on topology optimized design for additive manufacturing. IOP Conf. Ser. Mater. Sci. Eng. 2017, 276, 012026. [CrossRef]

114. Meng, F.; McKechnie, J.; Turner, T.A.; Pickering, S.J. Energy and environmental assessment and reuse of fluidised bed recycled carbon fibres. Compos. Part A Appl. Sci. Manuf. 2017, 100, 206-214. [CrossRef] 